\title{
MIGRATION AS AN ADJUSTMENT MECHANISM IN THE CRISIS? A COMPARISON OF EUROPE AND THE UNITED STATES ${ }^{1}$
}

\author{
Julia Jauer", Thomas Liebig*, John P. Martin* and Patrick A. Puhani\#
}

\begin{abstract}
The question of whether migration can be an equilibrating force in the labour market is an important criterion for an optimal currency area. It is of particular interest currently in the context of high and rising levels of labour market disparities, in particular within the Eurozone where there is no exchange-rate mechanism available to play this role. We shed some new light on this question by comparing pre- and post-crisis migration movements at the regional level in both Europe and the United States, and their association with asymmetric labour market shocks. We find that recent migration flows have reacted quite significantly to the EU enlargements in 2004 and 2007 and to changes in labour market conditions, particularly in Europe. Indeed, in contrast to the pre-crisis situation and the findings of previous empirical studies, there is tentative evidence that the migration response to the crisis has been considerable in Europe, in contrast to the United States where the crisis and subsequent sluggish recovery were not accompanied by greater interregional labour mobility in reaction to labour market shocks. Our estimates suggest that, if all measured population changes in Europe were due to migration for employment purposes - i.e. an upper-bound estimate - up to about a quarter of the asymmetric labour market shock would be absorbed by migration within a year. However, in the Eurozone the reaction mainly stems from migration of third-country nationals. Even within the group of Eurozone nationals, a significant part of the free mobility stems from immigrants from third countries who have taken on the nationality of their Eurozone host country.
\end{abstract}

\section{ACKNOWLEDGEMENTS}

This paper has benefited from the support of the European Commission (Directorate General for Employment, Social Affairs and Inclusion) in the framework of the joint EC-OECD project on "Matching economic migration with labour market needs". The authors would like to thank Laurent Aujean, JeanChristophe Dumont, Knut Gerlach, Alexander Hijzen, Stefano Scarpetta and the participants of the 3rd annual conference on "Immigration in OECD Countries" (Paris, 6 December 2013) for helpful comments.

1 *OECD, Paris, \#Leibniz Universität Hannover; CReAM, University College London; IZA, Bonn; SEW, University of St. Gallen; corresponding author: Patrick A. Puhani, Leibniz Universität Hannover, Institut für Arbeitsökonomik, Königsworther Platz 1, 30167 Hannover, Tel.: +49 511 762-5620, Fax: +49 511762 8297, Email: puhani@aoek.uni-hannover.de. 


\section{INTRODUCTION}

With the large and growing unemployment disparities in Europe in the wake of the global economic crisis, the question of whether or not free labour mobility can be an equilibrating force on the labour market is a highly topical one. In the EU-27, harmonised unemployment rates have risen between 2007 and early 2013 from $7.2 \%$ to $10.9 \%$. However, not all countries were equally affected. Whereas the unemployment rate rose in Greece and Spain by 18 percentage points over the same period, it actually declined in Germany, by more than 2 percentage points.

At the same time, there is a significant amount of free mobility in Europe whose scale has risen sharply following the EU enlargements in 2004 and 2007. According to the OECD standardised migration statistics, which cover only permanent migration movements across borders within OECD Europe, in 2011 intra-European free circulation was four times more common than migration from outside of the free mobility zone, exceeding more than 900000 migrants (OECD, 2013). OECD data also show that migration of the free-mobility type is the component in international migration flows that has reacted most strongly to the crisis.

In the United States, the labour market impact of the crisis across states has also been far from even, although the variation has been less marked than in Europe. Whereas the unemployment rate rose by roughly the same amount as in the EU-27 (from 4.6 to 7.8\% between 2007 and early 2013), Nevada saw an increase of more than 6 percentage points over that period, while North Dakota recorded no change.

This paper looks at the response of migration to differing labour market conditions, by analysing preand post-crisis migration movements in both Europe and the United States and how they have been linked to asymmetric economic shocks. We analyse both internal migration movements, that is of nationals of the free-mobility zone, and all migration flows. The issue of the responsiveness of migration to asymmetric shocks is particularly important for Europe, in the light of the recent shocks which have shaken the foundations of the Eurozone, a common currency area in which the exchange rate is no longer available as an instrument for adjusting to asymmetric shocks across countries within the region. At the same time, the European Union expanded its membership in 2004 and 2007 (as well as 2013, which is out of our sample period), increasing the scope for intra-EU mobility to play an equilibrating role in the face of adverse shocks $^{2}$.

2 See Kahanec (2012) for an extensive discussion of the effects of these two enlargements on labour mobility in Europe. 
The remainder of this paper is structured as follows. Section 1 contains a brief review of the literature on free mobility as an adjustment mechanism. Section 2 presents the data used for the analysis. Section 3 provides some descriptive information on recent trends in regional labour market disparities and population changes in both Europe and the United States. Section 4 provides an overview of the socio-economic characteristics of migrants within the respective free-mobility zones. Section 5 presents the empirical approach. Section 6 analyses the links between labour market disparities and migration responses. Section 7 concludes.

\section{PRIOR EMPIRICAL LITERATURE ON THE LINKS BETWEEN MIGRATION AND ECONOMIC CONDITIONS}

The issue of labour mobility as an adjustment mechanism in the face of economic shocks has received considerable attention in the literature, both in the United States and in Europe. More than 50 years ago, in his seminal paper on optimum currency areas, Mundell (1961) stressed the need for high labour and capital mobility as a shock absorber within a currency union: indeed, he argued that a high degree of factor mobility, especially labour mobility, is the defining characteristic of an optimum currency area. Thus, a key question when considering whether the Eurozone is an optimal currency area is: how important is labour mobility as an adjustment mechanism in Europe compared with its role in the United States? This is an empirical issue which has been examined in the literature.

Decressin and Fatás (1995), use a methodology developed by Blanchard et al. (1992) to find that employment shocks lead to a smaller migratory reaction in Europe than in the United States during the period 1968 to 1987. For the period 1981 to 1994, Bentivogli and Pagano (1999) obtain similar results. Von Weizsäcker (2008) agrees that internal mobility within the euro area is relatively low compared with mobility within the United States, but he argues that external immigration, i.e., from new EU member states and non-EU countries, can be a powerful substitute and thereby help assure the labour market adjustment process within the euro area, a judgement that is consistent with Puhani's (2001) findings for Italy. A high turnover in the labour market may be helpful for potential migrants to find jobs, enabling "outsiders" to compete more successfully for job vacancies with "insiders", as shown in a recent study of OECD countries by Martin and Scarpetta (2012). Christodoulakis and Mamatzakis (2010) and Jimeno and Bentolila (1998) argue that labour market rigidities lead to low employment rates and persistent regional labour market disparities in Greece and Spain, respectively. 
The accession of central and eastern European countries to the European Union in 2004 (by the Baltics, the Czech Republic, Hungary, Poland, the Slovak Republic and Slovenia) ${ }^{3}$ and 2007 (Bulgaria and Romania) has led to a set of studies investigating regional convergence in the accession countries and migratory responses to regional inequalities. Huber (2007) surveyed this literature, which in sum did not find regional convergence in these countries prior to accession. Instead, proximity to an intra-EU border and capital-city status seem to have fostered economic development. Fidrmuc (2004) even found that, despite growing regional disparities in the accession countries, measured by the coefficient of variation in wages and unemployment, overall migration flows have decreased. At least prior to their accession to the EU, migration contributed little to convergence between regions in EU accession countries, a fact that Huber (2007) sees as rooted in liquidity constraints and in imperfections in the housing market. Caroleo and Pastore (2010) also point to a poorly functioning rental market as a constraint for interregional migration flows within Europe. Heinz and Ward-Warmedinger (2006) stress that, apart from evident language barriers, there are still administrative barriers to free mobility, such as a less-than-full transferability of qualifications and labour market experience, which limit cross-country migration within the EU.

An example of regional developments within a recently created monetary union is the re-unification of West and East Germany in 1990. Monetary, economic and "social" union of the two parts of Germany led to a large real wage increase for East German workers which was not matched by a productivity convergence. As a result, unemployment rates remain high in the Eastern Länder compared with the Western Länder, more than 20 years after German re-unification. Although the circumstances associated with German monetary union of 1990 differ from those of the European monetary union about ten years later (1999), it is nevertheless interesting to compare those two cases. Unlike the Eurozone, the German "union" comprised not only monetary, but also fiscal and social policy union. This included large fiscal transfers from the Western to the Eastern Länder, a phenomenon that has not occurred in the Eurozone (Snower and Merkl, 2006). Nevertheless, there is evidence that despite this complete union and continuing interregional migration from the Eastern to the Western Länder, the two parts of Germany have not converged in many respects. Uhlig $(2006 ; 2008)$ documents this situation and explains it by a model in which so-called "networking externalities" keep jobs in the Western Länder and prevent capital and jobs following the significant fiscal transfers to the Eastern Länder. In a similar vein, Overman et al. (2002)

Two further countries also joined the EU in 2004. However, due to their small sizes and extremely limited migration potential, there was no concern about the potential labour market impact on other EU member countries. As a result, full freedom of movement was granted to their nationals by the other countries of the free-mobility zone directly upon accession - in contrast to the other countries, where transition arrangements applied in many countries. For an overview and a discussion, see OECD (2012). 
show evidence for polarization of unemployment rates in Western Europe and demonstrate that regional clusters need not respect national boundaries.

All of the above studies refer to the pre-crisis period. Regarding more recent trends, Molloy et al. (2011) review migration patterns within the United States over the past thirty years and find evidence for a secular decline in internal migration. Kaplan and Schulhofer-Wohl (2012) argue that this decline can largely be explained by easier learning about distant places before making a migration decision and by more homogeneity in returns to skills across regions. Molloy et al. (2011) also compare the experience of the United States with European data on within-country, inter-NUTS-2 mobility (see below), where the descriptive data show an upward trend in the second half of the 2000s, albeit the so-measured internal mobility still tends to be below that observed in the United States. ${ }^{4}$ A few recent studies have looked specifically at the impact of the crisis on mobility in Europe, with a particular focus on Germany which is not only the largest country in the Eurozone but also the country where labour market conditions have developed the most favourably since the beginning of the crisis. Elsner and Zimmermann (2013), on the basis of a descriptive overview of migration flows to Germany and economic conditions, conclude that while there has been an increase in immigration from countries hardest hit by the crisis, the flows in question are too small to have a large impact on reducing unemployment in origin countries. A similar conclusion has been reached by Bräuninger and Majowski (2011) who modeled the links between migration to Germany and wage and unemployment differentials with Greece, Ireland, Portugal and Spain. Bertoli et al. (2013) analysed the effect of the economic crisis on net migration of EU-27/EFTA nationals to Germany and argued that although differences in the economic conditions between the origin countries and Germany play a role in the observed increase in net migration to Germany between 2006 and 2012, changes in the relative attractiveness of alternative destinations are more important. Beine et al. (2013) analyse the reaction of gross bilateral migration flows between 30 OECD countries from 1980 and 2010 to differences in business cycles and employment rates between origin and destination countries. They find that labour mobility in Europe has increased over the period considered and has become more reactive to asymmetric shocks. Using the methodology developed by Blanchard et al. (1992), Dao et al. (2013) compare inter-state migration in the United States and mobility between 173 European regions in 21 countries and the response to regional labour demand shocks from 1998 to 2009. They find that the migration response to such shocks has increased in Europe over that period while it declined in the United States. They also find that the migration response has on average been larger in the countries which joined the EU in 2004 than in the EU-15 countries.

$4 \quad$ Note, however, that the data for Europe reported by Molloy et al (2011) cover the period until 2007, i.e. they cover only the pre-crisis period. 
In this paper, we will estimate the relationship between migration (proxied by population changes) and lagged regional unemployment and non-employment differentials. For reasons of data availability, we restrict ourselves to net migration, as we are not able to observe gross inflows and outflows separately (Coen-Pirani, 2010). Following Treyz et al. (1993), we only consider a one year lag and do not take into account the expectations of potential migrants' future labour earnings (Gallin, 2004; Kennan and Walker, 2011).

\section{DATA AND REGIONAL CLASSIFICATION}

The datasets used in this paper cover the EU-27/EFTA, the Eurozone, and the United States at two different levels of regional aggregation for the years 2005 to 2011. This period was chosen to cover both the crisis and the initial recovery period and the years preceding it; in addition, data at the more disaggregated regional level are only available consistently for both areas since 2005. The European freemobility zone is defined as the EU-27 plus the countries of the European Free Trade Association (EFTA) for the entire period. Note that in terms of labour mobility, the EFTA countries form part of the same labour market as the EU-27. We include all of these countries in the free-mobility zone for the entire period in spite of the fact that not all the countries in question formed part of the free-mobility zone throughout that period - in particular, Bulgaria and Romania joined the EU only in 2007 - and that a number of transitional measures applied. Indeed, migration flow data from a number of countries suggest that there was already significant migration from the new member countries prior to their accession to the European Union; a similar argument can be made for Switzerland regarding the gradual introduction of free mobility with the EU-15 (see OECD, 2012, for a discussion). In addition, immediately upon accession, all EU-27/EFTA countries had to introduce facilitations for nationals from the new EU member countries. For the purposes of this paper, the Eurozone is defined as the 17 member countries of the Euro currency union as of 2011, and comprises thus a subset of the EU-27/EFTA countries.

The period 2005-2012, to which we limit our analysis, followed the introduction of the euro as a common currency in 1999 and the EU enlargement in 2004 with the adhesion of ten new member countries to the EU and the gradual integration of Switzerland into the free-mobility zone. It has also been marked by the global economic crisis which started in 2008, and which had profound effects on both the labour markets of the EU-27/EFTA and the United States. The labour force survey data used for the analyses have been aggregated on a regional level for the entire EU-27/EFTA zone (including a subset for the Eurozone) and the USA. The sample has been restricted to the working-age population (i.e., persons aged 15-64). 
Data for the EU-27/EFTA and the Eurozone are taken from the European Labour Force Survey (LFS). In 2012, around 7.2 million interviews were conducted and the sampling rates in the participating countries vary between 0.2 and 3.3 per cent. The regional classification used for the EU-27/EFTA and Eurozone countries is the Nomenclature of Statistical Territorial Units (NUTS). The survey data used for the estimations are aggregated on both the basic regional (NUTS-2) and major regional (NUTS-1) levels. The number of observed NUTS-2 regions in the EU-27/EFTA and Eurozone estimations is 265 and 167, respectively, with an average of about 1.2 million working-age inhabitants per region for each of the two areas under consideration. For the estimations on the NUTS-1 level, 96 regions for the EU-27/EFTA and 62 for the Eurozone are included, each with an average of about 3.4 million inhabitants. As a proxy for regional income per capita, GDP per capita has been taken from the Eurostat REGIO database.

Data for the United States have been derived from the American Community Survey (ACS). In 2012, around 2.4 million interviews were conducted and the sampling rate is around 1 per cent. Compared with other large-scale US surveys, such as the Current Population Survey (CPS), the ACS has the advantage that it includes detailed geographic information below the state level on so-called Public Use Microdata Areas (PUMAs) since 2005. Note, however, that due to different methodologies, the ACS-measured unemployment is higher than that observed with data from the CPS.

Compared with Metropolitan areas, the PUMA regional classification has the advantage that it covers the whole territory (see also Molloy et al. 2011). PUMA regions are the smallest geographic entity available in the ACS and have an average of 100000 working-age inhabitants. The PUMAs are aggregated into larger units, the SuperPUMAs, of which there are 532 with an average of 382000 inhabitants in working age. This means that the NUTS-2 regions have a population that is about three times larger on average which tends to reduce the expected percentage of population changes relative to the United States. ${ }^{5}$ The equivalent to the NUTS-1 level is the state level in the United States, with an average working-age population of almost 4 million, which is very similar in the size to Europe's NUTS-1 regions. In contrast to the EU-27/EFTA, where GDP per capita has been used in the empirical analysis below as a proxy for regional income, a direct measure of income per capita at the regional level is available for the United States. $^{6}$

The unemployment rates are defined as the number of unemployed divided by the labour force (employed plus unemployed) of working age (15-64 years old), using the standard ILO definition for

\footnotetext{
5 Note, however, that the population density in the EU-27 area is also more than three times as high as the population density in the United States. 
unemployment. ${ }^{7}$ The non-employment rates are defined as the share of those not employed among the total working-age population. Population changes are measured by dividing the size of the population with the size of the population in the respective region one year earlier. Both the ACS and the LFS allow distinguishing between nationals and non-nationals in the regional population. For both data sets, weights are applied.

\section{REGIONAL DISPARITIES AND POPULATION CHANGES IN EUROPE AND THE UNITED STATES - AN OVERVIEW}

Figure 1 shows how unemployment has evolved in the EU-27/EFTA, the Eurozone and the United States since 2005. As can be seen, both Europe and the United States experienced a strong increase in unemployment rates with the crisis, i.e. between 2008 and 2010. While unemployment has fallen slightly in the United States since then, it has continued to grow - albeit at a slower pace - in the Eurozone. A further observation is that unemployment had declined quite significantly in Europe in the years just prior to the crisis, whereas the decline was only marginal in the United States.

Figure 1: Unemployment rates in the Eurozone, EU-27/EFTA and the United States, 2005-2011

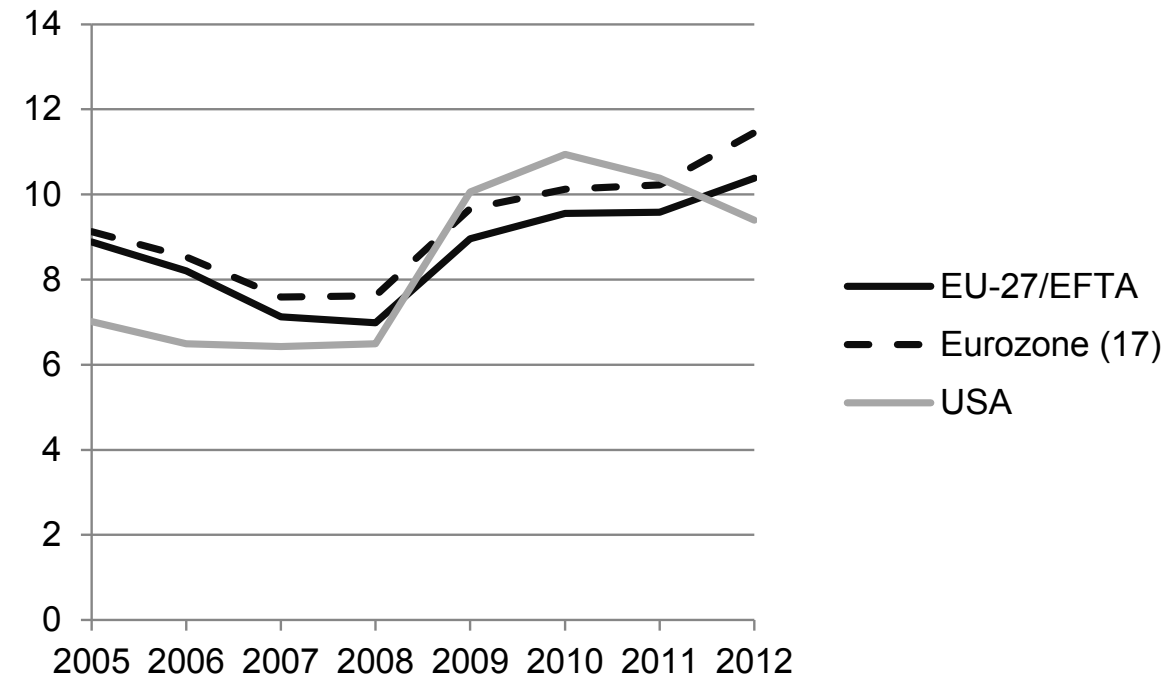

Source: European Labour Force Survey, American Community Survey.

7 According to the ILO definition, the unemployed comprise all persons who, during the week prior to the interview, were without work while both being available for work and seeking work. 
Figures $2 \mathrm{a}$ and $2 \mathrm{~b}$ depict regional unemployment rates in 2011, the evolution of the regional unemployment rates between 2006 and 2011 and the population change over that period in Europe and the United States at the NUTS-2 and SuperPUMA levels, respectively. In terms of unemployment, one observes a larger disparity in Europe than in the United States, both regarding 2011 levels of unemployment and the evolution since 2006, where the differences are particularly striking. In Europe, the impact on regions at the periphery is clearly visible. In contrast, the association between unemployment rates and the evolution of the working-age population is not obvious from these maps in either Europe or the United States. 
Figure 2a: Regional unemployment rates and population change for the EU-27/EFTA on the NUTS-2 level
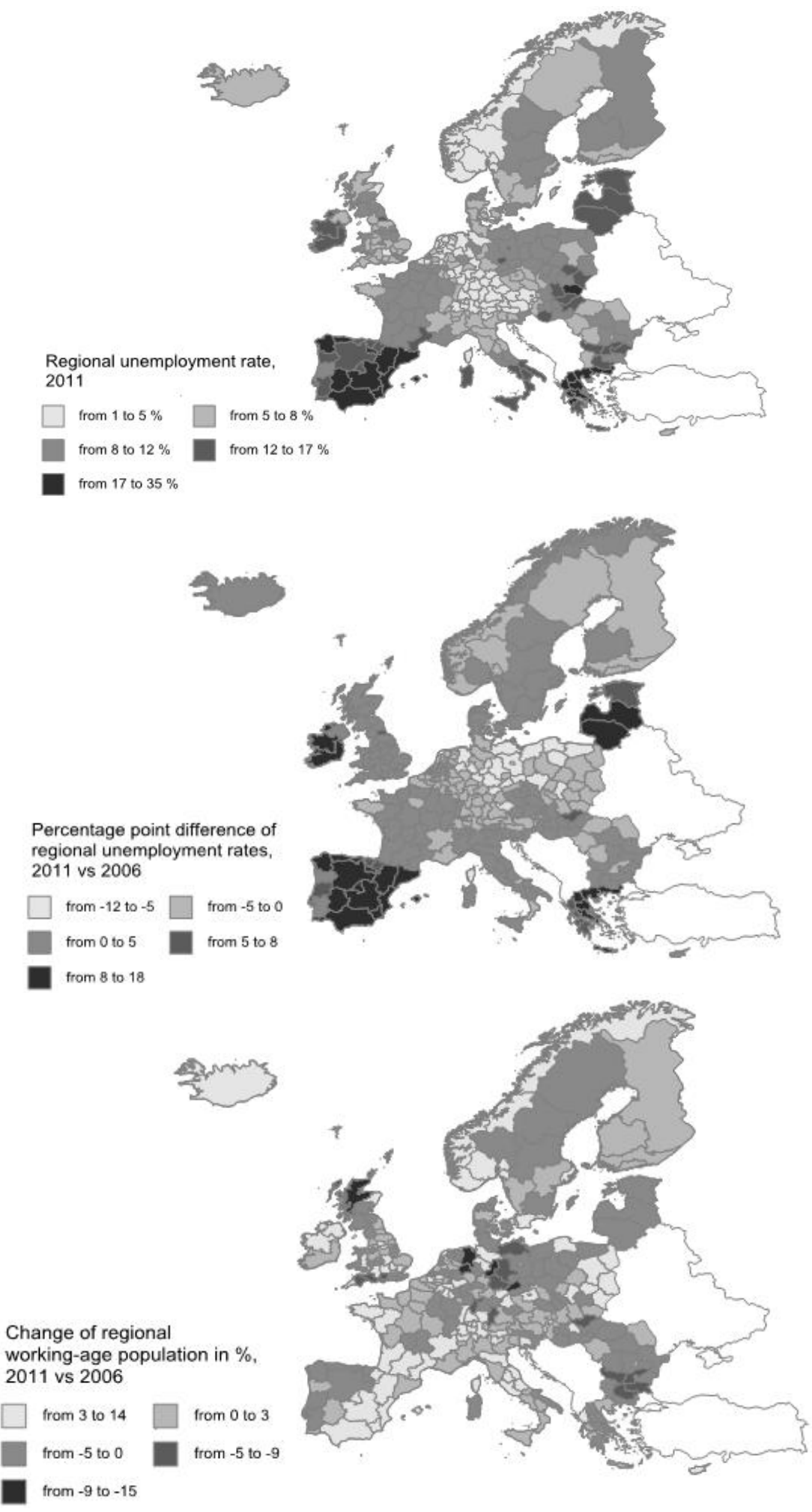

Source: European Labour Force Survey and EUROSTAT GISCO @ EuroGeographics.

Note: 2006 data for Denmark refer to 2007. 
Figure 2b: Regional unemployment rates and population change of for United States on SuperPUMA level
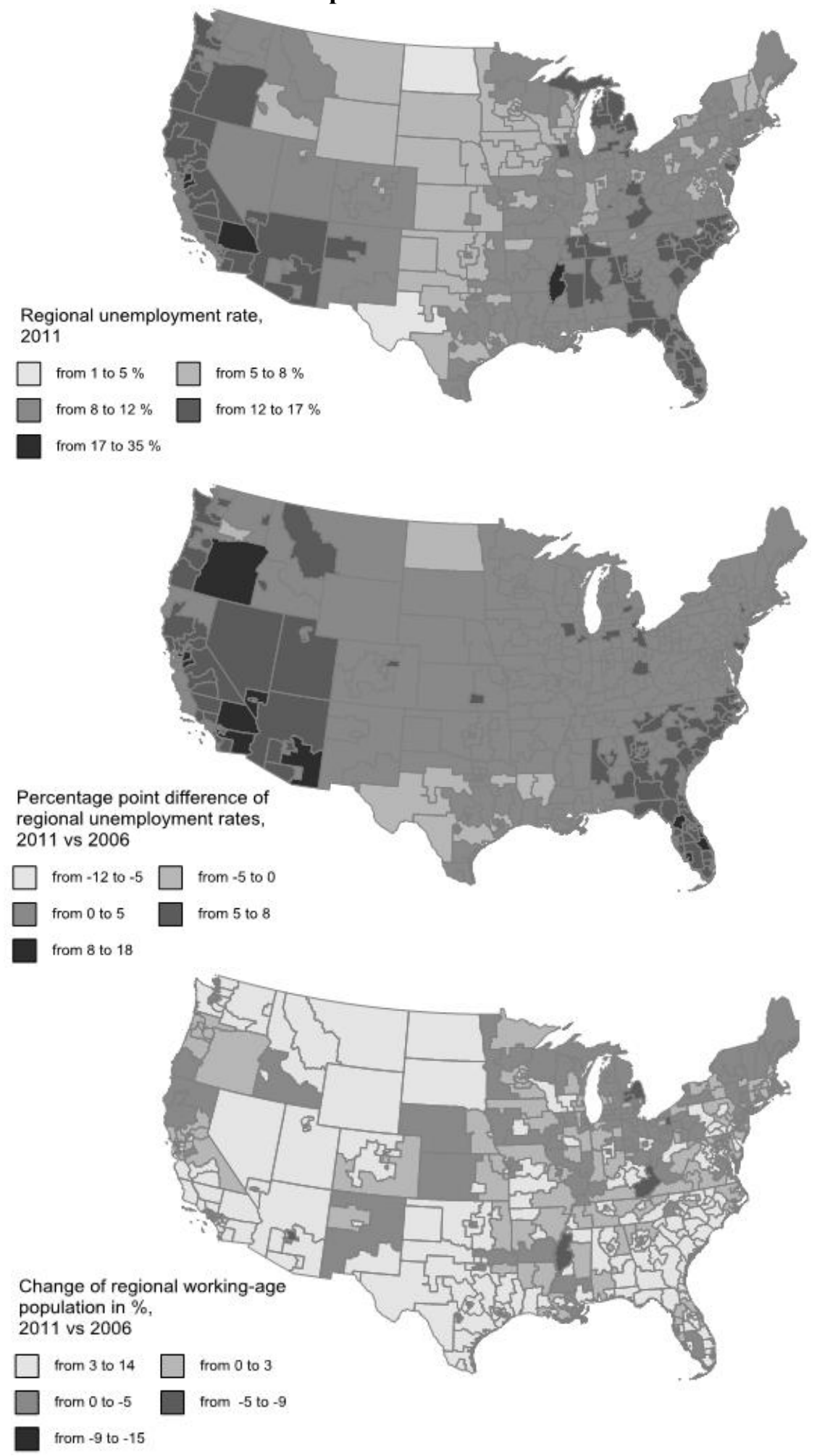

Source: American Community Survey and U.S. Census Bureau (C) Minnesota Population Center. 
At the NUTS-1 level, the lowest regional unemployment rate in Europe in 2011 was observed in the Finnish region of Åland (1\%), and the highest in the Spanish region of the Canary Islands (30\%). The Canary Islands were also the region which experienced the largest increase in unemployment rates over the five-year period, by more than 18 percentage points, whereas the unemployment rate declined in the five Eastern Länder of Germany by 7 to 9 percentage points. In the United States, the spread of state-level unemployment rates was much smaller, ranging from a low of about 3\% in North Dakota to a high of $13 \%$ in Michigan in 2011. A similar picture can be observed regarding the evolution of unemployment rates where disparities were also more modest in the United States, ranging from a modest decline of less than 1 percentage point in Alaska to an increase of about 8 percentage points in Nevada.

Interestingly, in terms of population changes, again three of the Eastern German Länder are on top of the list of population declines over that period, with declines of $7-8 \%$ of the working-age population in Saxony, Thuringia and Mecklenburg-Vorpommern. In contrast, Luxembourg (which is a country as well as a NUTS-1 and NUTS-2 region) experienced an increase of 13\%. Again, the changes in the United States were smaller, ranging from a 3\% decline in Michigan to a $9 \%$ increase in Utah and an $11 \%$ increase in the federal district of Washington. In summary, over the entire period and on the aggregate, both population changes and labour market disparities at the regional level were larger in Europe than in the United States.

Figure 3: Coefficients of variation in regional unemployment in Europe and in the United States

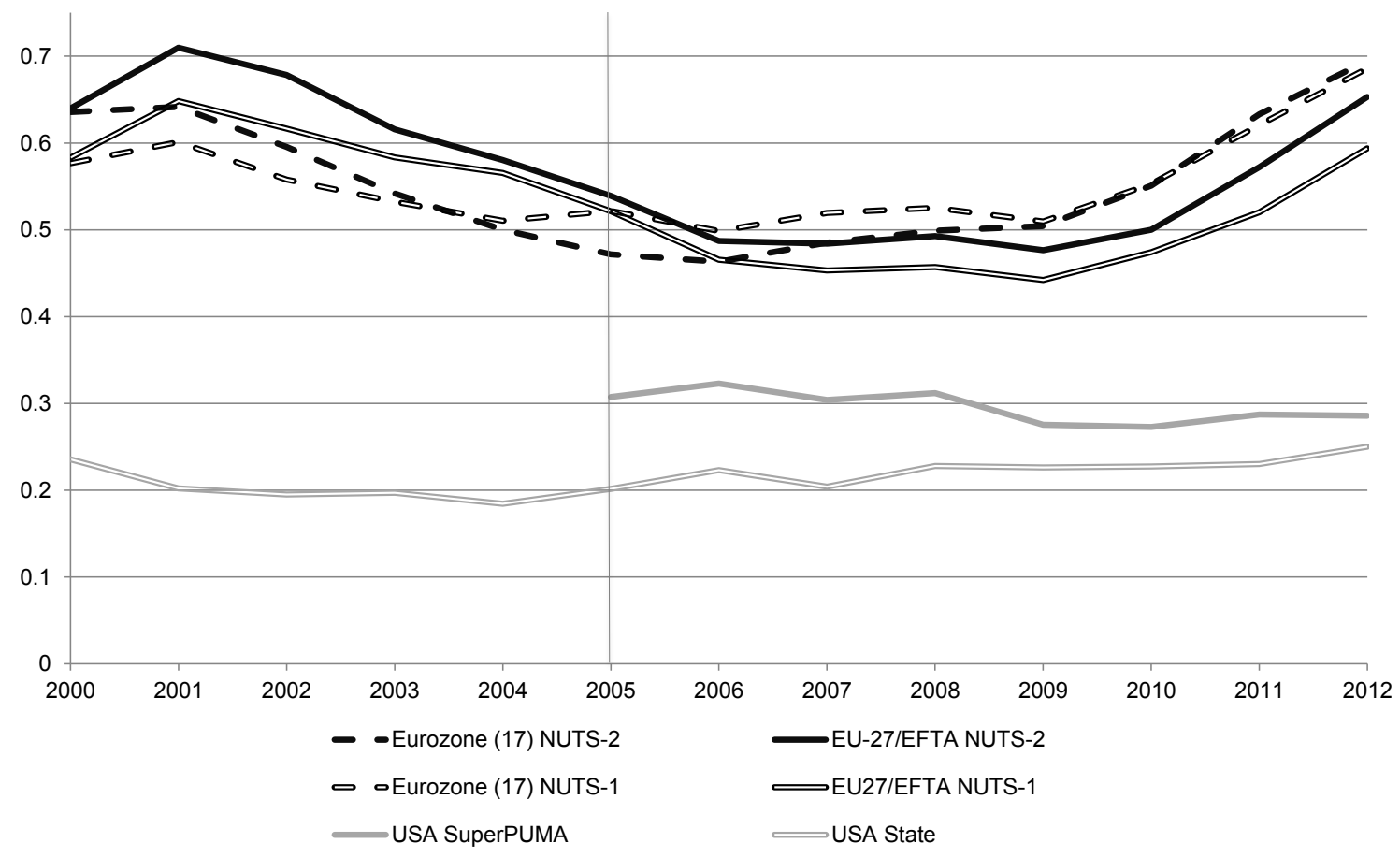

Source: European Labour Force Survey, American Community Survey. 
A synthetic measure of the interregional disparity in unemployment rates is given by the coefficient of variation of the unemployment rates, which is two to three times larger in Europe than in the United States (Figure 3). There is also much more cyclical variation in this measure in Europe, where a decline is observed until the beginning of the crisis and a strong increase since 2009, whereas no such changes are observed in the United States. This is particularly visible in the left part of Figure 3, which shows the coefficient of variation for Europe at NUTS-2 level starting in 2000, i.e. the year following the introduction of the common currency in the Eurozone. One also observes a stronger increase in the unemployment variation in the Eurozone compared with the whole EU-27/EFTA since the crisis, at both NUTS-1 and NUTS-2 levels. Hence, whereas regional unemployment variation in the Eurozone was smaller prior to the onset of the crisis, it is now larger than in the EU-27/EFTA region during the financial crisis. Finally, the level of variation is higher at the more disaggregate regional classifications in both Europe and the United States. Before turning to the links between unemployment differentials and migration, Section 4 provides an overview of the socio-economic characteristics of migrants within the respective free-mobility zone.

\section{SOCIO-ECONOMIC CHARACTERISTICS OF FREE-MOBILITY MIGRANTS IN EUROPE AND THE UNITED STATES}

Migration of nationals within the free-mobility area relative to the total population is considerably larger in the United States than in any other subgroup in the EU-27/EFTA. Free mobility, proxied by the percentage of persons who lived a year ago in a different state, accounted for almost $3 \%$ of the total population in the United States in 2005/2006 and has slightly decreased with the crisis (see Table 1). Free movement of citizens from one country to another within the EU-27/EFTA area relative to the total population is only about one tenth of that level. But contrary to the decline in the United States, it has increased somewhat from 2005/2006 to 2011/2012. However, mobility of nationals from the new EU member countries is much larger than that of the EU-27/EFTA as a whole, and also than that of nationals from Southern Europe (see also Annex 3).

The employment rate of recent EU-27/EFTA migrants is slightly higher than that of the non-mobile population, in marked contrast to what is observed in the United States. There are, however, important differences within the group of recent EU-27/EFTA migrants with respect to their labour market position in the destination country. Whereas nationals from Southern Europe who stay within the Eurozone have relatively low employment rates, employment rates are above-average for migrants who are EU-10 nationals. 
Interestingly, recent intra-Eurozone migrants were not necessarily the ones who were unemployed in their home country a year before moving. In fact, they faced slightly lower unemployment rates a year before than their peers who did not move. If they stayed within the Eurozone, they also did not see much of an increase in their employment rates either. This is in stark contrast notably to EU-2 migrants, who faced high unemployment rates one year before moving and who improved their employment rates considerably by migrating to another EU-27/EFTA country.

Free-mobility migrants within Europe are on average much younger and more highly-educated than the non-mobile population. This phenomenon is also observed in the United States, but to a lesser degree. Nationals from Southern Europe stand out with respect to their relatively high education level, with the majority having a tertiary-level degree. There is also some disparity within that group. Whereas the share of highly-educated migrants from Greece and Italy among migrants from these countries is in the vicinity of $60 \%$ and above, only about a quarter of the migrants from Portugal are highly educated. Associated with the relatively high formal education level is also a relatively high occupation level for those migrants from Southern Europe who managed to find employment.

Table 1: Characteristics of recent free-mobility migrants born in the respective area compared with the native-born population, $15-64$ years

\begin{tabular}{|c|c|c|c|c|c|c|c|c|c|c|c|c|c|c|c|}
\hline & \multicolumn{7}{|c|}{ 2005/2006 } & \multicolumn{7}{|c|}{ 2011/2012 } \\
\hline & & EU-27/EFT & Eurozone & $\begin{array}{l}\text { Southerr } \\
\text { EU-27/EF }\end{array}$ & $\begin{array}{l}\text { ope in } \\
\text { urozon }\end{array}$ & EU-10 & EU-2 & USA & EU-27/EFTA & Eurozone & $\begin{array}{l}\text { Southern } \\
\text { EU-27/EF }\end{array}$ & $\begin{array}{l}\text { ope in } \\
\text { urozon }\end{array}$ & EU-10 & EU2 & USA \\
\hline \multirow{11}{*}{ 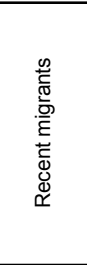 } & Employment rate, in \% & 65 & 58 & 61 & 54 & 75 & 66 & 58 & 67 & 60 & 70 & 59 & 71 & 58 & 52 \\
\hline & Unemployment rate, in \% & 12 & 14 & 16 & 21 & 8 & 12 & 14 & 10 & 16 & 12 & 15 & 8 & 17 & 18 \\
\hline & Non-employment rate, in \% & 35 & 42 & 39 & 46 & 25 & 34 & 42 & 33 & 40 & 30 & 41 & 29 & 42 & 48 \\
\hline & Employment rate one year ago, in \% & 56 & 48 & 52 & 46 & 65 & 56 & 82 & 59 & 58 & 58 & 51 & 61 & 49 & 76 \\
\hline & Unemployment rate one year ago, in \% & 17 & 18 & 16 & 21 & 10 & 14 & 9 & 13 & 9 & 15 & 15 & 13 & 26 & 12 \\
\hline & Non-employment rate one year ago, in $\%$ & 44 & 52 & 48 & 54 & 35 & 44 & 18 & 41 & 42 & 42 & 49 & 39 & 51 & 24 \\
\hline & Share of female, in $\%$ & 51 & 50 & 46 & 50 & 50 & 60 & 48 & 49 & 53 & 43 & 49 & 52 & 52 & 48 \\
\hline & Share of youth (20-34), in \% & 62 & 54 & 63 & 58 & 77 & 64 & 50 & 61 & 58 & 61 & 59 & 70 & 59 & 50 \\
\hline & Share of highly educated, in $\%$ & 28 & 34 & 23 & 24 & 19 & 19 & 38 & 40 & 41 & 51 & 41 & 28 & 24 & 39 \\
\hline & Share of highly skilled of employed, in $\%$ & 31 & 45 & 29 & 27 & 15 & 6 & 24 & 40 & 50 & 50 & 49 & 17 & 17 & 25 \\
\hline & Share as a $\%$ of origin population & 0.17 & 0.04 & 0.08 & 0.04 & 0.26 & 0.64 & 2.92 & 0.21 & 0.05 & 0.12 & 0.06 & 0.42 & 0.54 & 2.72 \\
\hline \multirow{10}{*}{ 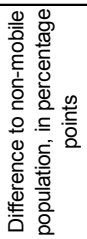 } & Employment rate, in \% & 1 & -7 & 0 & -6 & 18 & 8 & -10 & 3 & -4 & 13 & 2 & 10 & -1 & -11 \\
\hline & Unemployment rate, in \% & 4 & 6 & 8 & 13 & -5 & 5 & 7 & 1 & 6 & -3 & 0 & -2 & 9 & 7 \\
\hline & Non-employment rate, in \% & -1 & 7 & 0 & 6 & -18 & -8 & 10 & -3 & 4 & -13 & -2 & -10 & 1 & 11 \\
\hline & Employment rate one year ago, in \% & -6 & -14 & -6 & -12 & 9 & -1 & 2 & -4 & -5 & 1 & -6 & 0 & -11 & 3 \\
\hline & Unemployment rate one year ago, in \% & 7 & 7 & 4 & 9 & -4 & 4 & 1 & 2 & -3 & -4 & -4 & 1 & 14 & 1 \\
\hline & Non-employment rate one year ago, in $\%$ & 6 & 14 & 6 & 12 & -9 & 1 & -2 & 4 & 5 & -1 & 6 & 0 & 11 & -3 \\
\hline & Share of female, in $\%$ & 1 & 0 & -4 & 0 & -1 & 10 & -2 & 0 & 3 & -6 & 0 & 2 & 2 & -2 \\
\hline & Share of youth (20-34), in \% & 32 & 24 & 32 & 27 & 43 & 31 & 21 & 32 & 30 & 34 & 32 & 38 & 27 & 20 \\
\hline & Share of highly educated, in \% & 8 & 14 & 6 & 7 & 5 & 9 & 7 & 16 & 16 & 30 & 20 & 8 & 9 & 6 \\
\hline & Share of highly skilled of employed, in $\%$ & -8 & 5 & -7 & -9 & -20 & -17 & 0 & -1 & 8 & 14 & 12 & -19 & -8 & 0 \\
\hline
\end{tabular}

Note: Data are pooled over the two respective years, except for the United States where the data refer to 2011 , due to data availability. The share of highly-skilled of employed refers to the percentage of those in highly-skilled employment among all employed. Return migrants (migrants returning to their country or state of origin) are not included in the definition of recent migrants. Recent migrants are migrants who moved to the respective zone in the last year with the exception of migrants from the countries which joined the EU in 2007 and 2004 (i.e. the EU-2 and the EU-10, respectively) and from Southern Europe, who have moved to another EU-27/EFTA country and, in the latter case, to a country of the Eurozone. Eurozone countries are the 17 member countries since 2011. Southern Europe refers to Greece, Italy, Spain, and Portugal. The differences with the non-mobile population are calculated as mobile minus non-mobile population in the respective origin region. For example, $24 \%$ of recent free-mobility migrants from Romania and Bulgaria are highly-educated, compared with only $15 \%$ of the Romanians and Bulgarians who still reside in their origin country.

Source: European Labour Force Survey, American Community Survey. 
A further interesting observation is that naturalised immigrants in Europe are more mobile than natives and thus have a higher potential to alleviate regional labour market shocks than European natives. In results not shown in Table 1 , we find that $7.5 \%$ of the migrants with EU-27/EFTA nationality in $2011 / 2012$ were not born in that region. This share is about twice as large as their share among the entire population in the EU-27/EFTA. This shows that the intra-EU-27/EFTA mobility among this group, who already migrated at an earlier stage - in this case into Europe - is much larger than for native-born citizens. Thus, it appears that this group, which consists presumably of naturalised migrants, are more likely to migrate than the native-born. Naturalised migrants with a nationality from a country of Southern Europe, especially naturalised Spaniards, Italians and Portuguese, appear to be particularly mobile. The share of naturalised immigrants with Southern European nationality among the intra-EU-27/EFTA migrants from Southern Europe is about $17 \%$, that is about three times higher than the population share of naturalised immigrants in Southern Europe.

\section{EMPIRICAL APPROACH}

In the following, we measure shocks by increases in the regional un-/non-employment rate relative to the respective rate of the economic area of interest. ${ }^{8}$ Annex 1 provides an overview of the regions with the strongest changes. The unemployment rate is the standard indicator for labour market shocks. Many labour economists, however, like to supplement it with the non-employment (or employment) rate in order to get a more accurate picture of the state of the labour market (Cadena and Kovak, 2013). In the following, we will therefore use both indicators to measure the state of the labour market and the economy in general. Similar to a study by Puhani (2001) on labour mobility as a potential adjustment mechanism for economic shocks in Europe, we will investigate the statistical relationship between population changes in a region (both total population changes and changes induced by population changes of nationals within the freemobility area) and the regional unemployment rate relative to the overall unemployment rate in the freemobility area. Likewise, we include regional GDP/income per capita relative to the overall GDP/income per capita in the free-mobility area as a proxy for relative wages. ${ }^{9}$ As pointed out by Harris and Todaro (1970), migration is determined by the expected wage, which is a positive function of the wage and a negative function of the unemployment (or non-employment) rate.

\footnotetext{
8 We also include GDP/income per capita shocks. It would be preferable to include real wages but unfortunately such data are not available at the regional level.

By using relative measures, we assume that the decision to migrate or not is affected by the labour market situation in a given region relative to that elsewhere in the free-mobility area.
} 
Our model is based on the concept of the population growth factor generated by net migration in a region being "produced" by its un-/non-employment rate and income per capita level relative to the unemployment rate and income per capita in the whole economic area (here the EU-27/EFTA, the Eurozone, or the United States). ${ }^{10}$ Annex 1 shows the descriptive statistics for the relative un-/nonemployment rates. Hence, we set up the following production-function-like model:

$$
\frac{m i g_{i t}+\text { pop }_{i t-1}}{\text { pop }_{i t-1}}=A_{i t}\left(\frac{u r_{i t-1}^{\alpha_{1}} y_{i t-1}^{\alpha_{2}}}{u r_{n t-1}^{\alpha_{1}} y_{n t-1}^{\alpha_{2}}}\right)
$$

where mig indicates net migration and pop the population level. The relative unemployment rate $\left(\frac{u r_{i}}{u r_{n}}\right)$ in equation (1) equals the ratio of the unemployment rate in region $i$ and the unemployment rate of the whole economic area $n$ (EU-27/EFTA, Eurozone or United States). The relative non-employment rate $\left(\frac{n r_{i}}{n r_{n}}\right)$ is calculated in the same manner, as is the proxy measure of relative income per capita $\left(\frac{y_{i}}{y_{n}}\right)$.

Because our data do not allow us to observe net migration directly, we proxy the migration-induced population growth factor by the actual population growth factor as it is observed in the data. Hence,

$$
\frac{m i g_{i t}+p o p_{i t-1}}{\text { pop }_{i t-1}} \approx \frac{\Delta p o p_{i t}+p o p_{i t-1}}{\text { pop }_{i t-1}}=\frac{\text { pop }_{i t}}{\text { pop }_{i t-1}}
$$

The following regressions are estimated separately for two dependent variables. In a first set of regressions, the total population change in a region is the dependent variable. It is henceforth called the 'population growth factor' and is defined as $\left(\frac{\text { pop }_{i t}}{\text { pop }_{i t-1}}\right)$, where pop is the working-age population in region $i$. In a second set of regressions, the dependent variable is approximately the percentage change of the population that is induced by inter-regional movements of nationals of the free-mobility zone, hereafter referred to as the 'free-mobility-induced population growth factor'. It is defined as $\left(\frac{\Delta f m p_{i t}+p o p_{t-1}}{p o p_{t-1}}\right)$, where $\Delta f m p$ characterises the change (proxy for net migration) in the working-age population who are nationals of countries in the free-mobility area, that is $f m p_{i t}-f m p_{i t-1}$.

Thus, the simulated free-mobility-zone-migration-induced population change is the hypothetical population growth factor that would have been observed had the population only varied due to the changes in the number of free-mobility-zone migrants in that region. Ideally, we would like to measure migration-

By relating a flow (migration proxied by population change) to a stock (the lagged unemployment or nonemployment rate), we build on the matching function literature, which is based on an analogy to the production function where the flow of new hires is "produced" by the stock of unemployed workers and vacancies (see Petrongolo and Pissarides, 2001 for a survey of this literature). 
induced population change in all our regressions, but instead, the data only allow us to measure the total population change. This means, for example, that we also capture population ageing - if more people pass our upper age limit of 64 than our lower age limit of 15, this shows up as a negative population change (i.e. a population growth factor smaller than one) - even if no migration is taking place. Although we would much prefer to have data on interregional migration flows directly, this measurement error need not be a problem for our analysis: any measurement error that is constant over our estimation period in any given region (such as steady population aging) will not bias our estimates, because the region fixed effects will control for these time-constant measurement errors in the population change. To the extent that all regions in the free-mobility zone also experience a common trend in population ageing or any other measurement error, this measurement error will be controlled for by the fixed time (year) effects in our regressions. Even time-varying measurement error that is specific to certain regions will not bias our coefficient of interest as long as this measurement error is not correlated with either the relative unemployment or non-employment rate. $^{11}$

Combining expressions (1) and (2) and taking logs, we obtain the following estimating equation:

$$
\ln \left(\frac{\text { pop }_{i t}}{\text { pop }_{i t-1}}\right)=\alpha_{0}+\alpha_{1} \ln \left(\frac{u r_{i t-1}}{u r_{n t-1}}\right)+\ln \left(\frac{y_{i t-1}}{y_{n t-1}}\right)+\eta_{\mathrm{t}}+\mu_{\mathrm{i}}+\varepsilon_{\mathrm{it}}
$$

Note that the unemployment rate and the income variables for the whole economic area $u r_{n t-1}$ and $y_{n t-1}$, which are included in the denominators of the right-hand side of the estimating equation, do not vary over time and are thus captured by the time fixed effects $\eta_{t}$; the normalization of the regressors by these variables for the whole economic area therefore has no effect on the empirical estimates. A ceteris paribus increase of $1 \%$ in the number of unemployed people amounts to a ceteris paribus increase of $1 \%$ (not one percentage point) in the relative unemployment rate, because

$$
1.01 \times \frac{u r_{i t-1}}{u r_{n t-1}}=\frac{1.01 \times\left(\frac{u_{i t-1}}{w f_{i t-1}}\right)}{\left(\frac{u_{n t-1}}{w f_{n t-1}}\right)}
$$

In the first set of regressions, we simulate how many persons migrate in year $t$ for each additional person unemployed in year $t-1 .{ }^{12}$ By restricting the measurement of population change to migration of nationals from within the area under consideration in the second set of regressions, we can also isolate the

11 There is only a very small and insignificant correlation between the changes in the regional demographic structure (measured as the changes of the population ratio between 15-34 year olds and 35-64 year olds) and changes in regional un-/non-employment. indicate, not surprisingly, that this group tends to be more responsive to changes in the relative regional labour market conditions than the overall working-age population. 
size of the contribution of this particular group to the migratory response to regional unemployment dispersion and compare the intra-free mobility of the EU-27/EFTA area with interregional migration in the United States.

\section{ANALYSIS}

We estimate regressions at two different regional levels in the free-mobility areas under consideration (EU-27/EFTA, Eurozone and the United States). Both OLS and fixed effects (FE) regressions are estimated. The FE estimates control for time-constant unobserved factors, such as time-constant measurement errors or time-constant differences in amenities (climate, infrastructure) that are unobserved but have an impact on net migration into a region. Whereas the OLS estimator uses all the variation in the data (within and between regions), the FE estimator only uses the variation in the dependent and impact variables over time in each region, that is the so-called "within" variation in the data. The advantage of FE over OLS estimates is that time-constant unobserved factors (including measurement error) that influence net migration and are correlated with any impact variable will not lead to biased estimates once fixed region effects are included into the regression. We display coefficients for the full observation period 2006-2011 (because data on the lagged regressors unemployment and income per capita start already in 2005) and for the subperiods 2006-2008 (before the financial crisis) and 2009-2011 (after the financial crisis).

Table 2 shows the regression results for the full period (2006-2011). The OLS regressions generally indicate a statistically significant negative effect of relative unemployment on population growth, with the exception of the Eurozone at the NUTS-1 and the United States at state level, whereas none of the estimates for non-employment are both significant and positive. In contrast, in the FE specification almost all unemployment coefficients, with the exceptions of the Eurozone at the NUTS-1 and the United States at the SuperPUMA level, are significant. ${ }^{13}$ The coefficient of -0.017 for the Eurozone at NUTS-2 over the full period can be interpreted as follows: if the number of unemployed persons in the previous year increases by $1 \%$ ceteris paribus, the population growth rate in that region decreases by $0.017 \%$.

13 For estimates in Table 2, we have also experimented with Driscoll and Kraay (1998) standard errors, which allow for spatial correlation and autocorrelation of the errors terms. Several of the estimated standard errors were very similar to the reported standard errors, some were smaller, some bigger. Because Driscoll and Kraay (1998) standard errors require large $T$ (that is a large number of time periods) and because our observation period is fairly short, especially when we report results for subperiods, we only report heteroskedasticity-robust standard errors that are clustered by region (in the OLS estimates) here and in the following tables. 
In order to interpret the above coefficients correctly, we have to take into account that unemployed people are usually only a small fraction of the population. Therefore, in Annex 2 we interpret the estimation coefficients at the sample means. For example, the average number of unemployed people in a Eurozone NUTS-2 region in our sample over the whole period is about 82700 people. A 1\% increase in this number corresponds to 826 people. Thus, if unemployment in the previous year increases by 827 people, the population decreases by $0.017 \%$. How large is that number? The average population size for a Eurozone NUTS-2 region in our sample is 1286000 people, $0.017 \%$ of which are 219 people. Thus, 827 additional unemployed in a region in year $t-1$ decreases the population in the region in year $t$ by 219 people according to our estimates. This means that up to $27 \%$ of the unemployment increase may be offset by a population change/out-migration. This is non-negligible and higher than previous estimates, such as those reported by Puhani (2001) which suggest a migration offset of 4 and $8 \%$ over the period for Italy and France, respectively. ${ }^{14}$ Note, however, that these estimates provide upper bounds for the impact, since not all migration movements will be of unemployed people, and not all of those who move will take up employment elsewhere (see also our descriptive statistics in Section 3).

Table 3 disaggregates the results into the pre- and post-crisis periods, for the FE specification which is our preferred one. In general, we obtain negative coefficients both for the unemployment and the nonemployment measure, but due to limited sample sizes, not all of them are statistically significant. Here, it is interesting to observe that during the period of the financial crisis 2009-2011 (with the unemployment and income series referring to 2008 due to the lagged specification), our point estimates for the two European areas are much larger than for the period 2006-2008, whereas the reverse is the case in the United States. Indeed, our point estimates suggest that the pre-crisis labour mobility reaction to asymmetric labour market shocks was stronger in the United States than in Europe, in line with the previous results in the literature. However, this pattern appears to have changed quite drastically with the crisis, with Europe now showing a stronger interregional adjustment reaction than the United States. We find, for example at the NUTS-2 level in the EU-27/EFTA, that in the period 2009-2011 up to 37\% of the increase in unemployment was adjusted for by a population change, whereas the potential adjustment was only $7 \%$ and non-significant in the pre-crisis period (see the simulations in Table A3). For the estimates using relative non-employment as the impact variable, the simulation results are very similar, $36 \%$ during the crisis and an insignificant $12 \%$ in the pre-crisis period (Table A4).

14 These estimates refer to the period 1985 to 1996. For Western Germany, Puhani (2001) reported an estimated offset of up to $30 \%$; however, this period covered German reunification which was associated with large-scale movements from East to West Germany. 
Table 2: Unemployment, non-employment, and population change 2006-2011

\begin{tabular}{|c|c|c|c|c|c|c|}
\hline & $\begin{array}{c}\text { OLS } \\
\text { EU-27/ } \\
\text { EFTA }\end{array}$ & $\begin{array}{r}\text { OLS } \\
\text { Eurozone }\end{array}$ & $\begin{array}{l}\text { OLS } \\
\text { USA }\end{array}$ & $\begin{array}{r}\text { FE } \\
\text { EU-27I } \\
\text { EFTA }\end{array}$ & $\begin{array}{r}\text { FE } \\
\text { Eurozone }\end{array}$ & $\begin{array}{r}\text { FE } \\
\text { USA }\end{array}$ \\
\hline \multicolumn{7}{|c|}{ Effect of Lagged Relative Unemployment } \\
\hline \multicolumn{7}{|c|}{ NUTS-1/States } \\
\hline log relative unemployment rate & $-0.007^{* * *}$ & -0.002 & -0.004 & $-0.018^{* * *}$ & -0.009 & $-0.021^{* *}$ \\
\hline (s.e.) & $(0.002)$ & $(0.003)$ & $(0.004)$ & $(0.006)$ & $(0.006)$ & $(0.009)$ \\
\hline log relative income & $0.004^{* * *}$ & 0.003 & 0.006 & -0.010 & 0.036 & 0.058 \\
\hline (s.e.) & $(0.001)$ & $(0.004)$ & $(0.006)$ & $(0.009)$ & $(0.022)$ & $(0.04)$ \\
\hline R2 / R2 within & 0.120 & 0.030 & 0.508 & 0.108 & 0.058 & 0.616 \\
\hline Number of regions & 97 & 62 & 51 & 97 & 62 & 51 \\
\hline Number of time periods & 6 & 6 & 6 & 6 & 6 & 6 \\
\hline Number of observations & 578 & 368 & 305 & 578 & 368 & 305 \\
\hline \multicolumn{7}{|l|}{ NUTS-2/SuperPUMA } \\
\hline log relative unemployment rate & $-0.005^{* * *}$ & $-0.005^{* *}$ & $-0.006^{\star \star *}$ & $-0.016^{\star * \star}$ & $-0.017^{\star * \star}$ & -0.006 \\
\hline (s.e.) & $(0.001)$ & $(0.002)$ & $(0.002)$ & $(0.004)$ & $(0.006)$ & $(0.004)$ \\
\hline log relative income & $0.003^{* * *}$ & -0.001 & $0.004^{* *}$ & -0.008 & 0.005 & $0.034^{* *}$ \\
\hline (s.e.) & $(0.001)$ & $(0.003)$ & $(0.002)$ & $(0.009)$ & $(0.018)$ & $(0.017)$ \\
\hline R2 / R2 within & 0.024 & 0.009 & 0.222 & 0.022 & 0.017 & 0.251 \\
\hline Number of regions & 273 & 167 & 532 & 273 & 168 & 532 \\
\hline Number of time periods & 6 & 6 & 6 & 6 & 6 & 6 \\
\hline Number of observations & 1,605 & 985 & 3,182 & 1,605 & 985 & 3,182 \\
\hline \multicolumn{7}{|c|}{ Effect of Lagged Relative Non-employment } \\
\hline \multicolumn{7}{|c|}{ NUTS-1/States } \\
\hline log relative non-employment rate & 0.004 & $0.008^{* *}$ & 0.006 & $-0.092^{* \star *}$ & -0.022 & $-0.077^{* *}$ \\
\hline (s.e.) & $(0.004)$ & $(0.003)$ & $(0.006)$ & (0.019) & $(0.015)$ & $(0.033)$ \\
\hline log relative income & $0.006^{* * *}$ & $0.006^{*}$ & 0.008 & -0.009 & $0.040^{*}$ & 0.062 \\
\hline (s.e.) & $(0.001)$ & $(0.003)$ & $(0.005)$ & $(0.008)$ & $(0.023)$ & $(0.044)$ \\
\hline R2 / R2 within & 0.082 & 0.042 & 0.506 & 0.151 & 0.055 & 0.614 \\
\hline Number of regions & 97 & 62 & 51 & 97 & 62 & 51 \\
\hline Number of time periods & 6 & 6 & 6 & 6 & 6 & 6 \\
\hline Number of observations & 578 & 368 & 305 & 578 & 368 & 305 \\
\hline \multicolumn{7}{|l|}{ NUTS-2/SuperPUMA } \\
\hline log relative non-employment rate & -0.003 & 0.000 & -0.001 & $-0.087^{\star \star *}$ & $-0.099^{* * *}$ & $-0.087^{* * *}$ \\
\hline (s.e.) & $(0.003)$ & $(0.005)$ & $(0.004)$ & $(0.018)$ & $(0.024)$ & $(0.013)$ \\
\hline log relative income & $0.004^{* * *}$ & 0.003 & -0.001 & -0.006 & -0.000 & -0.007 \\
\hline (s.e.) & $(0.001)$ & $(0.002)$ & $(0.002)$ & $(0.007)$ & $(0.016)$ & $(0.016)$ \\
\hline R2 / R2 within & 0.018 & 0.004 & 0.219 & 0.033 & 0.035 & 0.263 \\
\hline Number of regions & 273 & 167 & 532 & 273 & 167 & 532 \\
\hline Number of time periods & 6 & 6 & 6 & 6 & 6 & 6 \\
\hline Number of observations & 1,605 & 985 & 3,182 & 1,605 & 985 & 3,182 \\
\hline
\end{tabular}

Note: $* * * \mathrm{p}<0.01,{ }^{* *} \mathrm{p}<0.05,{ }^{*} \mathrm{p}<0.1$. All regressions include year fixed effects.

Source: European Labour Force Survey, American Community Survey. 
Table 3: Unemployment, non-employment, and population change in Europe and the United States before and after the crisis

\begin{tabular}{|c|c|c|c|c|c|c|}
\hline & $\begin{array}{r}F E \\
\text { EU-27I } \\
\text { EFTA } \\
2006-08\end{array}$ & $\begin{array}{r}F E \\
\text { EU-27I } \\
\text { EFTA } \\
2009-11\end{array}$ & $\begin{array}{r}\text { FE } \\
\text { Eurozone } \\
2006-08\end{array}$ & $\begin{array}{r}\text { FE } \\
\text { Eurozone } \\
2009-11\end{array}$ & $\begin{array}{r}\text { FE } \\
\text { USA } \\
2006-08\end{array}$ & $\begin{array}{r}\text { FE } \\
\text { USA } \\
2009-11\end{array}$ \\
\hline \multicolumn{7}{|c|}{ Effect of Lagged Relative Unemployment } \\
\hline log relative unemployment rate & -0.003 & $-0.019^{*}$ & 0.009 & -0.009 & $-0.039^{*}$ & $-0.016^{*}$ \\
\hline (s.e.) & $(0.006)$ & $(0.011)$ & $(0.011)$ & $(0.014)$ & $(0.021)$ & $(0.009)$ \\
\hline log relative income & 0.001 & 0.049 & 0.030 & 0.074 & 0.016 & $0.121^{*}$ \\
\hline (s.e.) & $(0.01)$ & $(0.033)$ & $(0.025)$ & $(0.091)$ & $(0.079)$ & $(0.072)$ \\
\hline R2 / R2 within & 0.009 & 0.076 & 0.020 & 0.024 & 0.716 & 0.132 \\
\hline Number of regions & 97 & 97 & 62 & 62 & 51 & 51 \\
\hline Number of time periods & 3 & 3 & 3 & 3 & 3 & 3 \\
\hline Number of observations & 287 & 291 & 182 & 186 & 152 & 153 \\
\hline \multicolumn{7}{|l|}{ NUTS-2/SuperPUMA } \\
\hline log relative unemployment rate & -0.004 & $-0.025^{\star *}$ & 0.004 & -0.023 & -0.011 & -0.008 \\
\hline (s.e.) & $(0.01)$ & $(0.011)$ & $(0.026)$ & $(0.017)$ & $(0.007)$ & $(0.009)$ \\
\hline log relative income & 0.001 & 0.026 & 0.016 & 0.017 & $0.082^{* *}$ & -0.020 \\
\hline (s.e.) & $(0.017)$ & $(0.037)$ & $(0.033)$ & $(0.112)$ & $(0.035)$ & $(0.033)$ \\
\hline R2 / R2 within & 0.001 & 0.024 & 0.001 & 0.016 & 0.400 & 0.006 \\
\hline Number of regions & 273 & 272 & 167 & 167 & 531 & 532 \\
\hline Number of time periods & 3 & 3 & 3 & 3 & 3 & 3 \\
\hline Number of observations & 800 & 805 & 494 & 491 & 1,589 & 1,593 \\
\hline \multicolumn{7}{|c|}{ Effect of Lagged Relative Non-employment } \\
\hline \multicolumn{7}{|c|}{ NUTS-1/States } \\
\hline log relative non-employment rate & $-0.070^{* *}$ & $-0.135^{\star \star *}$ & 0.013 & -0.024 & -0.065 & -0.052 \\
\hline (s.e.) & $(0.032)$ & $(0.033)$ & $(0.018)$ & $(0.027)$ & 0.068 & 0.046 \\
\hline log relative income & -0.004 & 0.024 & 0.025 & 0.073 & 0.027 & 0.115 \\
\hline (s.e.) & $(0.01)$ & $(0.027)$ & $(0.022)$ & $(0.095)$ & $(0.072)$ & $(0.1)$ \\
\hline R2 / R2 within & 0.062 & 0.166 & 0.017 & 0.025 & 0.704 & 0.126 \\
\hline Number of regions & 97 & 97 & 62 & 62 & 51 & 51 \\
\hline Number of time periods & 3 & 3 & 3 & 3 & 3 & 3 \\
\hline Number of observations & 287 & 291 & 182 & 186 & 152 & 153 \\
\hline \multicolumn{7}{|l|}{ NUTS-2/SuperPUMA } \\
\hline log relative non-employment rate & -0.042 & $-0.130^{\star * *}$ & -0.060 & $-0.154^{\star * *}$ & $-0.135^{\star \star *}$ & -0.030 \\
\hline (s.e.) & $(0.048)$ & $(0.035)$ & $(0.085)$ & $(0.056)$ & $(0.022)$ & $(0.023)$ \\
\hline log relative income & -0.001 & 0.022 & 0.005 & -0.047 & 0.028 & -0.027 \\
\hline (s.e.) & $(0.016)$ & $(0.036)$ & $(0.03)$ & $(0.108)$ & $(0.034)$ & $(0.032)$ \\
\hline R2 / R2 within & 0.004 & 0.047 & 0.005 & 0.052 & 0.422 & 0.006 \\
\hline Number of regions & 273 & 272 & 167 & 167 & 531 & 532 \\
\hline Number of time periods & 3 & 3 & 3 & 3 & 3 & 3 \\
\hline Number of observations & 800 & 805 & 494 & 491 & 1,589 & 1,593 \\
\hline
\end{tabular}

Note: $* * * \mathrm{p}<0.01,{ }^{* *} \mathrm{p}<0.05, * \mathrm{p}<0.1$. All regressions include year fixed effects.

Source: European Labour Force Survey, American Community Survey. 
Up to now, we have looked at the association between labour market disparities and all migrationinduced population changes. Of particular interest is the population change that is generated by nationals within the free-mobility zone, as nationals of third countries from outside the respective region do not necessarily enjoy the same mobility rights. ${ }^{15}$ Tables 4 and 5 present the OLS and FE results under this alternative specification, for the full period in the former table, and the FE results disaggregated between the pre- and post-crisis periods in the latter. In general, and not surprisingly, restricting the sample to nationals from within the free-mobility zone tends to weaken the association somewhat. This holds particularly in the Eurozone, where per-capita migration flows from nationals outside of the free-mobility zone are much higher than in the United States (see OECD, 2013; Cadena and Kovak, 2013, still demonstrate that Mexican migrants played a significant role in the absorption of labour market shocks in the United States during the crisis). Despite of a weaker association between regional population changes and labour market shocks for nationals, most significant coefficients maintain the expected sign when restricting population changes in the dependent variable to those induced by nationals only. What is striking, however, is that in both Tables 4 and 5, the coefficients for the Eurozone exhibit no estimates that are both negative and statistically significant. This contrasts with the estimates for the EU-27/EFTA, where negative and statistically significant estimates are also found for migration due to nationals of the free mobility zone, particularly for non-employment during the crisis years 2009-2001. Taking these different sets of estimates for the Eurozone and the EU-27/EFTA together, we conclude that labour market adjustment in Europe during the crisis was driven primarily by citizens from outside the Eurozone, such as the recent EU accession countries or non-EU-27/EFTA countries.

\footnotetext{
15 However, it is possible that part of the measured effect arises from naturalisations, i.e. immigrants with a non-EU-27/EFTA nationality taking up citizenship of their respective host countries - and this is, as we have seen in Box 1, a group that is particularly mobile. To see how this might influence our results, we also ran our estimations for population change that is induced only by inter-regional movements of persons born within the free-mobility zone, thus excluding immigrants born outside the EU-27/EFTA area who obtained EU-27/EFTA nationality in the meantime. The results, which are available upon request, remain similar to the results presented in Tables 4 and 5, but the coefficients are slightly smaller and have somewhat lower tstatistics.
} 
Table 4: Unemployment, non-employment, and population change generated by nationals of the area under consideration

\begin{tabular}{|c|c|c|c|c|c|c|}
\hline & $\begin{array}{r}\text { OLS } \\
\text { EU-27/ } \\
\text { EFTA }\end{array}$ & $\begin{array}{r}\text { OLS } \\
\text { Eurozone }\end{array}$ & $\begin{array}{l}\text { OLS } \\
\text { USA }\end{array}$ & $\begin{array}{r}\mathrm{FE} \\
\text { EU-27/ } \\
\text { EFTA } \\
\end{array}$ & $\begin{array}{r}\text { FE } \\
\text { Eurozone }\end{array}$ & $\begin{array}{r}\text { FE } \\
\text { USA }\end{array}$ \\
\hline \multicolumn{7}{|c|}{ Effect of Lagged Relative Unemployment } \\
\hline \multicolumn{7}{|c|}{ NUTS-1/States } \\
\hline log relative unemployment rate & $-0.005^{\star \star *}$ & -0.000 & -0.004 & -0.005 & $0.008^{*}$ & $-0.021^{* *}$ \\
\hline (s.e.) & $(0.002)$ & $(0.002)$ & $(0.004)$ & $(0.006)$ & $(0.004)$ & $(0.009)$ \\
\hline log relative income & $0.004^{* \star *}$ & -0.001 & 0.005 & -0.002 & 0.025 & 0.034 \\
\hline (s.e.) & $(0.001)$ & $(0.003)$ & $(0.005)$ & $(0.012)$ & $(0.021)$ & $(0.031)$ \\
\hline R2 / R2 within & 0.087 & 0.040 & 0.454 & 0.046 & 0.055 & 0.547 \\
\hline Number of regions & 97 & 62 & 51 & 97 & 62 & 51 \\
\hline Number of time periods & 6 & 6 & 6 & 6 & 6 & 6 \\
\hline Number of observations & 578 & 368 & 305 & 578 & 368 & 305 \\
\hline \multicolumn{7}{|l|}{ NUTS-2/SuperPUMA } \\
\hline log relative unemployment rate & $-0.003^{* * *}$ & -0.002 & $-0.005^{* * *}$ & -0.006 & 0.001 & $-0.007^{*}$ \\
\hline (s.e.) & $(0.001)$ & $(0.002)$ & $(0.002)$ & $(0.004)$ & $(0.005)$ & $(0.004)$ \\
\hline log relative income & $0.003^{* * *}$ & -0.001 & $-0.004^{* \star}$ & -0.001 & 0.007 & 0.005 \\
\hline (s.e.) & $(0.001)$ & $(0.002)$ & $(0.002)$ & $(0.009)$ & $(0.018)$ & $(0.016)$ \\
\hline R2 / R2 within & 0.018 & 0.013 & 0.196 & 0.009 & 0.013 & 0.219 \\
\hline Number of regions & 273 & 167 & 532 & 273 & 167 & 532 \\
\hline Number of time periods & 6 & 6 & 6 & 6 & 6 & 6 \\
\hline Number of observations & 1,605 & 985 & 3,182 & 1,605 & 985 & 3,182 \\
\hline \multicolumn{7}{|c|}{ Effect of Lagged Relative Non-employment } \\
\hline \multicolumn{7}{|l|}{ NUTS-1/States } \\
\hline log relative non-employment rate & 0.005 & $0.005^{\star *}$ & 0.005 & $-0.034^{* *}$ & $0.021^{*}$ & $-0.076^{* *}$ \\
\hline (s.e.) & $(0.004)$ & $(0.002)$ & $(0.006)$ & $(0.016)$ & $(0.011)$ & $(0.031)$ \\
\hline log relative income & $0.006^{\star \star *}$ & 0.001 & 0.007 & -0.003 & 0.023 & 0.040 \\
\hline (s.e.) & $(0.002)$ & $(0.003)$ & $(0.005)$ & $(0.01)$ & $(0.019)$ & $(0.04)$ \\
\hline R2 / R2 within & 0.070 & 0.047 & 0.452 & 0.053 & 0.054 & 0.543 \\
\hline Number of regions & 97 & 62 & 51 & 97 & 62 & 51 \\
\hline Number of time periods & 6 & 6 & 6 & 6 & 6 & 6 \\
\hline Number of observations & 578 & 368 & 305 & 578 & 368 & 305 \\
\hline \multicolumn{7}{|l|}{ NUTS-2/SuperPUMA } \\
\hline log relative non-employment rate & -0.001 & 0.000 & -0.000 & $-0.029^{*}$ & -0.016 & $-0.087^{\star \star \star}$ \\
\hline (s.e.) & $(0.003)$ & $(0.004)$ & $(0.003)$ & $(0.016)$ & $(0.023)$ & $(0.012)$ \\
\hline log relative income & $0.004^{* \star *}$ & 0.001 & -0.002 & -0.001 & 0.001 & $-0.035^{* *}$ \\
\hline (s.e.) & $(0.001)$ & $(0.002)$ & $(0.002)$ & $(0.008)$ & $(0.017)$ & $(0.016)$ \\
\hline R2 / R2 within & 0.015 & 0.012 & 0.194 & 0.011 & 0.014 & 0.231 \\
\hline Number of regions & 273 & 167 & 532 & 273 & 167 & 532 \\
\hline Number of time periods & 6 & 6 & 6 & 6 & 6 & 6 \\
\hline Number of observations & 1,605 & 985 & 3,182 & 1,605 & 985 & 3,182 \\
\hline
\end{tabular}

Note: $* * * \mathrm{p}<0.01,{ }^{* *} \mathrm{p}<0.05,{ }^{*} \mathrm{p}<0.1$. All regressions include year fixed effects.

Source: European Labour Force Survey, American Community Survey. 
Table 5: Unemployment, non-employment, and population change generated by nationals of the area under consideration, before and after the crisis

\begin{tabular}{|c|c|c|c|c|c|c|}
\hline & $\begin{array}{r}F E \\
\text { EU-27I } \\
\text { EFTA } \\
2006-08\end{array}$ & $\begin{array}{r}F E \\
\text { EU-27I } \\
\text { EFTA } \\
2009-11\end{array}$ & $\begin{array}{r}\text { FE } \\
\text { Eurozone } \\
\\
2006-08\end{array}$ & $\begin{array}{r}\text { FE } \\
\text { Eurozone } \\
2009-11\end{array}$ & $\begin{array}{r}\text { FE } \\
\text { USA } \\
2006-08\end{array}$ & $\begin{array}{r}\text { FE } \\
\text { USA } \\
2009-11\end{array}$ \\
\hline \multicolumn{7}{|c|}{$\begin{array}{l}\text { Effect of Lagged Relative Unemployment } \\
\text { NUTS-1/State }\end{array}$} \\
\hline $\begin{array}{l}\text { log relative unemployment rate } \\
\text { (s.e.) }\end{array}$ & $\begin{array}{r}0.005 \\
(0.008)\end{array}$ & $\begin{array}{r}-0.001 \\
(0.013)\end{array}$ & $\begin{array}{l}0.053^{* *} \\
(0.022)\end{array}$ & $\begin{array}{r}0.003 \\
(0.012)\end{array}$ & $\begin{array}{l}-0.042^{*} \\
(0.022)\end{array}$ & $\begin{array}{r}-0.022^{* * *} \\
(0.007)\end{array}$ \\
\hline $\begin{array}{l}\text { log relative income } \\
\text { (s.e.) }\end{array}$ & $\begin{array}{l}-0.029 \\
(0.057)\end{array}$ & $\begin{array}{l}0.065^{\star} \\
(0.037)\end{array}$ & $\begin{array}{l}0.113^{* *} \\
(0.048)\end{array}$ & $\begin{array}{l}-0.007 \\
(0.122)\end{array}$ & $\begin{array}{r}0.025 \\
(0.066)\end{array}$ & $\begin{array}{r}0.089 \\
(0.083)\end{array}$ \\
\hline R2 / R2 within & 0.075 & 0.048 & 0.208 & 0.005 & 0.640 & 0.090 \\
\hline Number of regions & 97 & 97 & 62 & 62 & 51 & 51 \\
\hline Number of time periods & 3 & 3 & 3 & 3 & 3 & 3 \\
\hline Number of observations & 287 & 291 & 182 & 186 & 152 & 153 \\
\hline \multicolumn{7}{|l|}{ NUTS-2/SuperPUMA } \\
\hline $\begin{array}{l}\text { log relative unemployment rate } \\
\text { (s.e.) }\end{array}$ & $\begin{array}{l}0.003 \\
(0.01)\end{array}$ & $\begin{array}{r}-0.009 \\
(0.01)\end{array}$ & $\begin{array}{r}0.030 \\
(0.025)\end{array}$ & $\begin{array}{r}0.002 \\
(0.015)\end{array}$ & $\begin{array}{r}-0.013^{* *} \\
(0.006)\end{array}$ & $\begin{array}{r}-0.009 \\
(0.008)\end{array}$ \\
\hline $\begin{array}{l}\text { log relative income } \\
\text { (s.e.) }\end{array}$ & $\begin{array}{r}-0.005 \\
(0.032)\end{array}$ & $\begin{array}{r}0.025 \\
(0.035)\end{array}$ & $\begin{array}{r}0.059^{*} \\
(0.035)\end{array}$ & $\begin{array}{r}-0.013 \\
(0.098)\end{array}$ & $\begin{array}{r}0.059^{*} \\
(0.031)\end{array}$ & -0.052 \\
\hline $\begin{array}{l}\text { (s.e.) } \\
\text { R2 / R2 within }\end{array}$ & $\begin{array}{r}(0.032) \\
0.008\end{array}$ & $\begin{array}{r}(0.035) \\
0.008\end{array}$ & $\begin{array}{r}(0.035) \\
0.032\end{array}$ & $\begin{array}{r}(0.098) \\
0.007\end{array}$ & $\begin{array}{r}(0.031) \\
0.350\end{array}$ & $\begin{array}{r}(0.032) \\
0.004\end{array}$ \\
\hline Number of regions & 273 & 272 & 167 & 167 & 531 & 532 \\
\hline Number of time periods & 3 & 3 & 3 & 3 & 3 & 3 \\
\hline Number of observations & 800 & 805 & 494 & 491 & 1,589 & 1,593 \\
\hline \multicolumn{7}{|c|}{ Effect of Lagged Relative Non-employment } \\
\hline $\begin{array}{l}\text { log relative non-employment rate } \\
\text { (s.e.) }\end{array}$ & $\begin{array}{l}0.057 \\
(0.04)\end{array}$ & $\begin{aligned}-0.081^{* *} \\
(0.037)\end{aligned}$ & $\begin{array}{r}0.110^{* * *} \\
(0.023)\end{array}$ & $\begin{array}{l}-0.005 \\
(0.022)\end{array}$ & $\begin{array}{l}-0.058 \\
(0.069)\end{array}$ & $\begin{array}{l}-0.073 \\
(0.062)\end{array}$ \\
\hline $\begin{array}{l}\text { log relative income } \\
\text { (s.e.) }\end{array}$ & $\begin{array}{r}-0.027 \\
(0.05)\end{array}$ & $\begin{array}{r}0.036 \\
(0.032)\end{array}$ & $\begin{array}{l}0.091^{* *} \\
(0.037)\end{array}$ & $\begin{array}{l}-0.022 \\
(0.118)\end{array}$ & $\begin{array}{r}0.045 \\
(0.069)\end{array}$ & $\begin{array}{r}0.080 \\
(0.123)\end{array}$ \\
\hline R2 / R2 within & 0.086 & 0.091 & 0.221 & 0.004 & 0.622 & 0.080 \\
\hline Number of regions & 97 & 97 & 62 & 62 & 51 & 51 \\
\hline Number of time periods & 3 & 3 & 3 & 3 & 3 & 3 \\
\hline Number of observations & 287 & 291 & 182 & 186 & 152 & 153 \\
\hline \multicolumn{7}{|l|}{ NUTS-2/SuperPUMA } \\
\hline $\begin{array}{l}\text { log relative non-employment rate } \\
\text { (s.e.) }\end{array}$ & $\begin{array}{r}0.031 \\
(0.043)\end{array}$ & $\begin{array}{l}-0.062^{*} \\
(0.032)\end{array}$ & $\begin{array}{r}0.078 \\
(0.075)\end{array}$ & $\begin{array}{l}-0.055 \\
(0.052)\end{array}$ & $\begin{array}{r}-0.145^{\star * *} \\
(0.02)\end{array}$ & $\begin{array}{l}-0.023 \\
(0.023)\end{array}$ \\
\hline log relative income & -0.005 & 0.021 & 0.047 & -0.065 & 0.002 & $-0.056^{*}$ \\
\hline (s.e.) & $(0.03)$ & $(0.034)$ & $(0.031)$ & $(0.098)$ & $(0.031)$ & $(0.033)$ \\
\hline R2 / R2 within & 0.009 & 0.016 & 0.029 & 0.015 & 0.378 & 0.004 \\
\hline Number of regions & 273 & 272 & 167 & 167 & 531 & 532 \\
\hline Number of time periods & 3 & 3 & 3 & 3 & 3 & 3 \\
\hline Number of observations & 800 & 805 & 494 & 491 & 1,589 & 1,593 \\
\hline
\end{tabular}

Note: $* * * \mathrm{p}<0.01, * * \mathrm{p}<0.05, * \mathrm{p}<0.1$. All regressions include year fixed effects.

Source: European Labour Force Survey, American Community Survey. 


\section{CONCLUSION}

This paper aimed at analysing the migration response to asymmetric labour market conditions in the pre- and post-crisis periods in Europe and the United States. We find that prior to the crisis, the migration response to labour market shocks was stronger in the United States, in line with previous results in the literature. This picture appears to have changed with the crisis and the evidence suggests that migration in Europe seems to have reacted quite strongly to changes in labour market conditions - more so than in the United States, where internal mobility seems to have declined, at least over the initial post-crisis period 2009-2011

The increase in labour mobility in Europe is linked to the EU enlargements of 2004 and 2007 which greatly increased the scope of free labour mobility within the EU/EFTA and the Eurozone. By doing so, it added to the adjustment capacity of the labour markets to cope with asymmetric shocks. It is also conceivable that there may be threshold effects at work, i.e. that intra-European mobility has grown disproportionately only once labour market disparities have reached a certain level. Indeed, these disparities have widened more strongly with the crisis in Europe than in the United States and are now, in terms of unemployment at the larger regional level, more than twice as large in Europe as in the United States.

As the economic gaps within the Eurozone are large and widening, the "push" factors for more emigration from the Southern periphery countries and Ireland should remain strong in the coming years. Although it cannot, by itself, be the sole solution to resist negative shocks, one would thus expect labour migration flows to reach significant levels and to help in reducing labour market disparities. ${ }^{16}$ However, our findings suggest that within the Eurozone, adjustment due to labour migration occurred mostly due to citizens from recent EU accession countries or non-EU-27/EFTA countries, and less from citizens within the Eurozone. In addition, a significant part of the effect attributed to citizens from these countries seems to stem from naturalised immigrants. Raising the contribution of Eurozone citizens to labour market adjustment within the Eurozone requires a continued move towards freer movement of labour within Europe. While this is not certain given the current unfavourable climate of public opinion in many countries towards increased migration for employment, the evidence presented in this paper suggests that it

16 Note also that the flows from Southern Europe continue to grow, albeit at relatively low levels. The example of Germany, together with the United Kingdom the largest recipient of these flows, illustrates this well. In the first half of 2013, new registered inflows of citizens from Spain and Italy to Germany increased by about $40 \%$ compared with the first half of 2012 . Inflows of Portuguese increased by more than $25 \%$ while those of Greeks declined slightly. However, flows from all four of these countries were still only $2 / 3$ of those of Poles alone, and even slightly below those of Romanians. 
would have favourable effects in terms of helping labour mobility to be a key adjustment mechanism against asymmetric shocks. 


\section{BIBLIOGRAPHY}

Beine, M., P. Bourgeon and J.-C. Bricongne (2013), “Aggregate Fluctuations and International Migration”, CESifo Working Paper No. 4379.

Bentivogli, Ch. and P. Pagano (1999), "Regional Disparities and Labour Mobility: the Euro-11 versus the USA"; Labour, 13, 737-760.

Bertoli, S., H. Brücker and J. Fernández-Huertas Moraga (2013), “The European Crisis and Migration to Germany. Expectations and the Diversion of Migration Flows", IZA Discussion Paper No. 7170.

Blanchard, O.J., L.F Katz, R. E. Hall and B. Eichengreen (1992), "Regional Evolutions”, Brookings Papers on Economic Activity, 1, 1-75.

Bräuninger, D. and C. Majowski (2011), "Labour mobility in the euro area". Deutsche Bank Research, Reports on European integration EU Monitor 85.

Cadena, B.C. and B.K. Kovak (2013), "Immigrants Equilibrate Local Labor Markets: Evidence from the Great Recession”, NBER Working Paper No. 19727, Cambridge, MA.

Caroleo, F.E. and F. Pastore (2010), "Structural Change and Labour Reallocation Across Regions: A Review of the Literature", in: Caroleo, F.E. and F. Pastore (eds.): The Labour Market Impact of EU Enlargement, A New Regional Geography of Europe?, 17-47, Heidelberg: Physica/Springer.

Christodoulakis, G.A. and E.C. Mamatzakis (2010), "Labour Market Dynamics in Greek Regions: A Bayesian Markov Chain Approach Using Proportions Data", Review of Economic Analysis, 2, 32-45.

Coen-Pirani, D. (2010), "Understanding Gross Worker Flows Across U.S. States”, Journal of Monetary Economics, 57, 769-784.

Dao, M., D. Furceri, and P. Loungani (2013), "Regional labour market adjustments in the US and Europe", forthcoming IMF Working Paper.

Decressin, J. and A. Fatás (1995), "Regional labor market dynamics in Europe”. European Economic Review, 39, 1627-1655.

Driscoll, J.C. and A.C. Kraay (1998): Consistent Covariance Matrix Estimation with Spatially Dependent Panel Data, Review of Economics and Statistics, 80, 549-560.

Elsner, B. and K.F. Zimmermann (2013), "10 Years After. EU Enlargement, Closed Borders, and Migration to Germany", IZA Discussion Paper No. 7130.

Fidrmuc, J. (2004), "Migration and Regional Adjustment to Asymmetric Shocks in Transition Economies", Journal of Comparative Economics, 32, 230-247.

Gallin, J.H. (2004), "Net Migration and State Labor Market Dynamics", Journal of Labor Economics, 22, $1-21$.

Harris, J.R. and M.P. Todaro (1970), “Migration, Unemployment and Development: A Two-Sector Analysis", American Economic Review, 60, 126-142. 
Heinz, F.F. and M. Ward-Warmedinger (2006), "Cross-Border Labour Mobility Within An Enlarged EU", Occasional Paper Series No. 52, European Central Bank.

Huber, P. (2007), "Regional Labour Market Developments in Transition: A Survey of the Empirical Literature", European Journal of Comparative Economics, 4, 263-298.

Kaplan, G. and S. Schulhofer-Wohl (2012), "Understanding the Long-Run Decline in Interstate Migration, NBER Working Paper No. 18507, Cambridge, MA.

Jimeno, J.F. and S. Bentolila (1998), "Regional Unemployment Persistence (Spain, 1976-1994)”, Labour Economics, 5, 25-51.

Kahanec, M. (2012), "Labor Mobility in an Enlarged European Union”, IZA Discussion Paper No. 6485, Bonn.

Kennan, J. and J.R. Walker (2011), "The Effect of Expected Income on Individual Migration Decisions", Econometrica 79: 211-251.

Martin, J.P. and S. Scarpetta (2012), "Setting It Right: Employment Protection, Labour Reallocation and Productivity", De Economist, Springer, 160(2), 89-116.

Molloy, R.; C.L. Smith and A.K. Wozniak (2011), "Internal Migration in the United States", National Bureau of Economic Research Working Paper No. 17307.

Mundell, R.A. (1961), “A Theory of Optimum Currency Areas”, American Economic Review, 51, 657-665.

OECD (2013), International Migration Outlook. OECD Publishing, Paris.

OECD (2012), Free Movement of Workers and Labour Market Adjustment - Recent Experiences from OECD Countries and the European Union. OECD Publishing, Paris.

Overman, H.G., D. Puga and H. Vandenbussche (2002), “Unemployment Clusters Across Europe's Regions and Countries", Economic Policy, 17, 115-147.

Petrongolo, B. and C. A. Pissarides (2001), "Looking into the Black Box: A Survey of the Matching Function”, Journal of Economic Literature, 39, 390-431.

Puhani, P.A. (2001), "Labour Mobility. An Adjustment Mechanism in Euroland? Empirical Evidence for Western Germany, France and Italy", German Economic Review, 2, 127-140.

Snower, D.J. and C. Merkl (2006), "The Caring Hand that Cripples: The East German Labor Market after Reunification", American Economic Review, 96, 375-382.

Treyz, G.I., D.S. Rickman, G.L. Hunt and M.J. Greenwood (1993), “The Dynamics of U.S. Internal Migration", Review of Economics and Statistics, 75, 209-214.

Uhlig, H. (2006), "Regional Labor Markets, Network Externalities and Migration: The Case of German Reunification", American Economic Review Papers and Proceedings, 96, 383-387.

Uhlig, H. (2008), “The Slow Decline of East Germany”, Journal of Comparative Economics, 36, 517-541. 
Von Weizsäcker, J. (2008), "Divisions of Labour: rethinking Europe's migration policy”, Bruegel Blueprint Series, No. 6, Brussels. 


\section{ANNEX 1: RELATIVE UNEMPLOYMENT AND NON-EMPLOYMENT RATES}

The relative unemployment rate, i.e. the ratio of the regional unemployment rate and the overall unemployment rate in the area under consideration, can take any non-negative real number. For example, the NUTS-2 region "Oberfranken" in Germany had a regional unemployment rate of around $13.3 \%$ in 2006. The unemployment rate in the whole EU-27/EFTA zone was around $8.2 \%$. The relative unemployment rate is thus:

$$
\frac{\text { regional unemployment rate }}{\text { unemployment rate in EU27/EFTA }}=\frac{13.3}{8.2} \approx 1.62
$$

By 2011, the regional unemployment rate of "Oberfranken" had declined to around $3.4 \%$, while the unemployment rate of the EU-27/EFTA increased to $9.6 \%$ and the relative unemployment rate therefore decreased to 0.35 , i.e. a decline by 1.27 . The decrease of the relative unemployment rate in "Oberfranken" was the strongest in the whole sample, followed closely by other German regions, which also saw big decreases in the relative unemployment rate (see Table A1). In contrast, the strongest increases in the relative unemployment rate were observed in several NUTS-2 regions in Spain headed by "Canarias" where the regional unemployment rate increased from $11.8 \%$ in 2006 to $29.8 \%$ in 2011 . This resulted in a relative unemployment rate of about 1.42 in 2006 and 3.1 in 2011. The same measure can be applied to non-employment; Table A2 below provides an overview of the regions with the strongest changes. 
Table A1: Evolution of the relative unemployment rate between 2006 and 2011

\begin{tabular}{|c|c|c|c|c|c|c|c|}
\hline & \multicolumn{3}{|c|}{ EU-27/EFTA } & \multicolumn{3}{|c|}{ USA } \\
\hline & & Country & NUTS-2 region & & State & Superpi & \\
\hline \multirow[t]{4}{*}{ bottom 10} & 1 & Germany & Oberfranken & -1.258 & Pennsylvania & 42152 & -0.903 \\
\hline & 2 & Germany & Mecklenburg-Vorpommern & -1.312 & Illinois & 17505 & -0.717 \\
\hline & 3 & Germany & Chemnitz & -1.242 & Texas & 48240 & -0.703 \\
\hline & 4 & Germany & Thüringen & -1.152 & Texas & 48040 & -0.646 \\
\hline \multirow{6}{*}{ 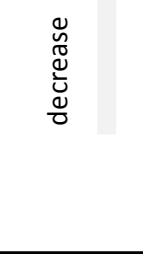 } & 5 & Germany & Brandenburg & -1.099 & Pennsylvania & 42153 & -0.642 \\
\hline & 6 & Germany & Dresden & -1.063 & Louisiana & 22100 & -0.625 \\
\hline & 7 & Germany & Sachsen-Anhalt & -1.077 & Louisiana & 22200 & -0.621 \\
\hline & 8 & Germany & Berlin & -1.044 & Washington & 53040 & -0.617 \\
\hline & 9 & Poland & Dolnoslaskie & -0.997 & Arkansas & 05500 & -0.592 \\
\hline & 10 & Germany & Bremen & -0.950 & Michigan & 26124 & -0.587 \\
\hline \multirow[t]{10}{*}{ top 10} & 10 & Spain & Aragón & 1.113 & California & 06301 & 0.513 \\
\hline & 9 & Ireland & Border, Midland and Western & 1.135 & Florida & 12082 & 0.526 \\
\hline & 8 & Spain & Extremadura & 0.992 & California & 06071 & 0.547 \\
\hline & 7 & Spain & Cataluña & 1.214 & Nevada & 32201 & 0.554 \\
\hline & 6 & Spain & Castilla-La Mancha & 1.319 & California & 06122 & 0.599 \\
\hline & 5 & Spain & Illes Balears & 1.500 & California & 06202 & 0.604 \\
\hline & 4 & Spain & Comunidad Valenciana & 1.544 & California & 06702 & 0.614 \\
\hline & 3 & Spain & Región de Murcia & 1.696 & Florida & 12120 & 0.614 \\
\hline & 2 & Spain & Andalucía & 1.636 & Florida & 12100 & 0.636 \\
\hline & 1 & Spain & Canarias & 1.679 & Florida & 12150 & 0.688 \\
\hline
\end{tabular}

Note: The French Region "Corse" is not reported above because of unresolved discrepancies with published data from Eurostat.

Source: European Labour Force Survey, American Community Survey. 
Table A2: Evolution of the relative non-employment rate between 2006 and 2011

\begin{tabular}{|c|c|c|c|c|c|c|c|}
\hline & \multicolumn{3}{|c|}{ EU-27/EFTA } & \multicolumn{3}{|c|}{ USA } \\
\hline & & Country & NUTS-2 region & & State & Superpi & \\
\hline \multirow[t]{4}{*}{ bottom 10} & 1 & Germany & Chemnitz & -0.468 & Texas & 48130 & -0.193 \\
\hline & 2 & Germany & Braunschweig & -0.292 & Illinois & 17503 & -0.180 \\
\hline & 3 & Germany & Thüringen & -0.287 & New York & 36121 & -0.175 \\
\hline & 4 & Germany & Oberfranken & -0.282 & Mississippi & 28600 & -0.170 \\
\hline \multirow{6}{*}{ 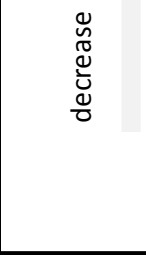 } & 5 & Germany & Sachsen-Anhalt & -0.243 & Louisiana & 22702 & -0.168 \\
\hline & 6 & Germany & Koblenz & -0.236 & Texas & 48185 & -0.166 \\
\hline & 7 & Germany & Brandenburg & -0.217 & New York & 36111 & -0.152 \\
\hline & 8 & Germany & Mecklenburg-Vorpommern & -0.215 & Ohio & 39040 & -0.147 \\
\hline & 9 & Germany & Detmold & -0.212 & Texas & 48250 & -0.136 \\
\hline & 10 & Germany & Lüneburg & -0.208 & Alaska & 02100 & -0.134 \\
\hline \multirow[t]{10}{*}{ top 10} & 10 & Spain & Castilla-La Mancha & 0.200 & California & 06071 & 0.162 \\
\hline & 9 & Spain & Aragón & 0.206 & Florida & 12085 & 0.163 \\
\hline & 8 & Spain & Cataluña & 0.216 & Ohio & 39030 & 0.163 \\
\hline & 7 & Spain & Andalucía & 0.236 & Florida & 12120 & 0.166 \\
\hline & 6 & Ireland & Southern and Eastern & 0.240 & Florida & 12070 & 0.171 \\
\hline & 5 & Spain & Canarias & 0.278 & Florida & 12081 & 0.176 \\
\hline & 4 & Spain & Región de Murcia & 0.280 & Nevada & 32202 & 0.180 \\
\hline & 3 & Ireland & Border, Midland and Western & 0.288 & Florida & 12150 & 0.190 \\
\hline & 2 & Spain & Comunidad Valenciana & 0.311 & California & 06705 & 0.192 \\
\hline & 1 & Spain & Illes Balears & 0.338 & Florida & 12060 & 0.216 \\
\hline
\end{tabular}

Note: The French Region Corse is not reported above because of unresolved discrepancies with published data from Eurostat.

Source: European Labour Force Survey, American Community Survey. 


\section{ANNEX 2: SIMULATIONS}

Table A3: Simulated unemployment adjustment due to migration (based on FE models)

\begin{tabular}{|c|c|c|c|c|c|c|}
\hline & Coeff. & $\begin{array}{c}\text { Average } \\
\text { Number of } \\
\text { Unemployed }\end{array}$ & $\begin{array}{c}\text { Average } \\
\text { Population }\end{array}$ & $\begin{array}{c}1 \text { Percent } \\
\text { Change in } \\
\text { Unemployment }\end{array}$ & $\begin{array}{l}\text { Migration- } \\
\text { Induced } \\
\text { Population } \\
\text { Change } \\
\end{array}$ & $\begin{array}{l}\text { Unemployment } \\
\text { Adjustment due } \\
\text { to Migration (\%) }\end{array}$ \\
\hline \multicolumn{7}{|c|}{ Larger Regions } \\
\hline \multicolumn{7}{|c|}{ EU-27/EFTA NUTS-1 } \\
\hline $2006-2011$ & -0.018 & 206497 & 3409413 & 2065 & 623 & 30 \\
\hline 2006-2008 & $(-0.003)$ & 180681 & 3369941 & 1807 & $(101)$ & (6) \\
\hline 2009-2011 & -0.019 & 231957 & 3448342 & 2320 & 664 & 29 \\
\hline \multicolumn{7}{|c|}{ Only EU Citizens' Migration } \\
\hline $2006-2011$ & $(-0.005)$ & 206497 & 3409413 & 2065 & $(180)$ & $(9)$ \\
\hline $2006-2008$ & $(0.005)$ & 180681 & 3369941 & 1807 & $(-153)$ & $(-8)$ \\
\hline $2009-2011$ & $(-0.001)$ & 231957 & 3448342 & 2320 & $(24)$ & $(1)$ \\
\hline \multicolumn{7}{|c|}{ Eurozone NUTS-1 } \\
\hline \multicolumn{7}{|c|}{ All Migration } \\
\hline $2006-2011$ & $(-0.009)$ & 154345 & 2232272 & 1543 & $(196)$ & $(13)$ \\
\hline $2006-2008$ & $(0.009)$ & 132702 & 2194048 & 1327 & $(-190)$ & $(-14)$ \\
\hline 2009-2011 & $(-0.009)$ & 175636 & 2269876 & 1756 & (199) & $(11)$ \\
\hline \multicolumn{7}{|c|}{ Only Eurozone Citizens' Migration } \\
\hline $2006-2011$ & 0.008 & 154345 & 2232272 & 1543 & -170 & -11 \\
\hline 2006-2008 & 0.053 & 132702 & 2194048 & 1327 & -1166 & -88 \\
\hline $2009-2011$ & $(0.003)$ & 175636 & 2269876 & 1756 & $(-76)$ & $(-4)$ \\
\hline \multicolumn{7}{|c|}{ USA States } \\
\hline \multicolumn{7}{|c|}{ All Migration } \\
\hline $2006-2011$ & -0.021 & 247921 & 4034056 & 2479 & 846 & 34 \\
\hline 2006-2008 & -0.039 & 188277 & 4000513 & 1883 & 1545 & 82 \\
\hline $2009-2011$ & -0.016 & 307176 & 4067379 & 3072 & 652 & 21 \\
\hline \multicolumn{7}{|c|}{ Only US Citizens' Migration } \\
\hline $2006-2011$ & -0.021 & 247921 & 4034056 & 2479 & 867 & 35 \\
\hline 2006-2008 & -0.042 & 188277 & 4000513 & 1883 & 1696 & 90 \\
\hline 2009-2011 & -0.022 & 307176 & 4067379 & 3072 & 910 & 30 \\
\hline \multicolumn{7}{|c|}{ Smaller Regions } \\
\hline \multicolumn{7}{|c|}{ EU-27/EFTA NUTS-2 } \\
\hline \multicolumn{7}{|c|}{ All Migration } \\
\hline $2006-2011$ & -0.016 & 74492 & 1232524 & 745 & 203 & 27 \\
\hline 2006-2008 & $(-0.004)$ & 65510 & 1229990 & 655 & $(43)$ & (7) \\
\hline $2009-2011$ & -0.025 & 83419 & 1235043 & 834 & 307 & 37 \\
\hline \multicolumn{7}{|c|}{ Only EU Citizens' Migration } \\
\hline $2006-2011$ & $(-0.006)$ & 74492 & 1232524 & 745 & $(70)$ & $(9)$ \\
\hline $2006-2008$ & $(0.003)$ & 65510 & 1229990 & 655 & $(-40)$ & $(-6)$ \\
\hline 2009-2011 & $(-0.009)$ & 83419 & 1235043 & 834 & $(112)$ & (13) \\
\hline \multicolumn{7}{|c|}{ Eurozone NUTS-2 } \\
\hline \multicolumn{7}{|c|}{ All Migration } \\
\hline $2006-2011$ & -0.017 & 82731 & 1286070 & 827 & 223 & 27 \\
\hline $2006-2008$ & $(0.004)$ & 72263 & 1277757 & 723 & $(-47)$ & $(-7)$ \\
\hline 2009-2011 & $(-0.023)$ & 93263 & 1294433 & 933 & (297) & (32) \\
\hline \multicolumn{7}{|c|}{ Only Eurozone Citizens' Migration } \\
\hline $2006-2011$ & $(0.001)$ & 82731 & 1286070 & 827 & $(-18)$ & $(-2)$ \\
\hline $2006-2008$ & $(0.030)$ & 72263 & 1277757 & 723 & $(-385)$ & $(-53)$ \\
\hline 2009-2011 & $(0.002)$ & 93263 & 1294433 & 933 & $(-29)$ & $(-3)$ \\
\hline \multicolumn{7}{|c|}{ USA SuperPUMA } \\
\hline All Migratio & & & & & & \\
\hline 2006-2011 & $(-0.006)$ & 23696 & 385768 & 237 & $(24)$ & $(10)$ \\
\hline $2006-2008$ & $(-0.011)$ & 17958 & 381686 & 180 & (42) & (23) \\
\hline $2009-2011$ & $(-0.008)$ & 29420 & 389840 & 294 & (31) & (10) \\
\hline Only US Ci & & & & & & \\
\hline 2006-2011 & -0.007 & 23696 & 385768 & 237 & 27 & 11 \\
\hline $2006-2008$ & -0.013 & 17958 & 381686 & 180 & 50 & 28 \\
\hline 2009-2011 & $(-0.009)$ & 29420 & 389840 & 294 & (34) & (11) \\
\hline
\end{tabular}

Note: Values in brackets are not within significance level of $\mathrm{p}<0.1$.

Source: European Labour Force Survey, American Community Survey. 
Table A4: Simulated non-employment adjustment due to migration (based on FE models)

\begin{tabular}{|c|c|c|c|c|c|c|}
\hline & Coeff. & $\begin{array}{c}\text { Average } \\
\text { Number of } \\
\text { Non-employed }\end{array}$ & $\begin{array}{l}\text { Average } \\
\text { Population }\end{array}$ & $\begin{array}{c}1 \text { Percent } \\
\text { Change in Non- } \\
\text { employment }\end{array}$ & $\begin{array}{l}\text { Migration- } \\
\text { Induced } \\
\text { Population } \\
\text { Change } \\
\end{array}$ & $\begin{array}{c}\text { Non- } \\
\text { employment } \\
\text { Adjustment due } \\
\text { to Migration (\%) }\end{array}$ \\
\hline \multicolumn{7}{|c|}{$\begin{array}{l}\text { Larger Regions } \\
\text { EU-27/EFTA NUTS-1 }\end{array}$} \\
\hline \multicolumn{7}{|c|}{ All Migration } \\
\hline 2005-2011 & -0.092 & 1200046 & 3409413 & 12000 & 3152 & 26 \\
\hline 2005-2007 & -0.070 & 1171137 & 3369941 & 11711 & 2355 & 20 \\
\hline 2008-2011 & -0.135 & 1228557 & 3448342 & 12286 & 4668 & 38 \\
\hline \multicolumn{7}{|c|}{ Only EU Citizens' Migration } \\
\hline $2005-2011$ & -0.034 & 1200046 & 3409413 & 12000 & 1160 & 10 \\
\hline 2005-2007 & $(0.057)$ & 1171137 & 3369941 & 11711 & $(-1923)$ & $(-16)$ \\
\hline 2008-2011 & -0.081 & 1228557 & 3448342 & 12286 & 2795 & 23 \\
\hline \multicolumn{7}{|c|}{ Eurozone NUTS-1 } \\
\hline $2005-2011$ & $(-0.022)$ & 489122 & 2232272 & 4891 & $(499)$ & (10) \\
\hline 2005-2007 & $(0.013)$ & 466720 & 2194048 & 4667 & $(-296)$ & $(-6)$ \\
\hline 2008-2011 & $(-0.024)$ & 511043 & 2269876 & 5110 & (541) & (11) \\
\hline \multicolumn{7}{|c|}{ Only Eurozone Citizens' } \\
\hline $2005-2011$ & 0.021 & 489122 & 2232272 & 4891 & -462 & -9 \\
\hline 2005-2007 & 0.110 & 466720 & 2194048 & 4667 & -2421 & -52 \\
\hline 2008-2011 & $(-0.005)$ & 511043 & 2269876 & 5110 & $(113)$ & (2) \\
\hline \multicolumn{7}{|c|}{$\begin{array}{l}\text { USA States } \\
\text { All Migration }\end{array}$} \\
\hline 2005-2011 & -0.077 & 1358869 & 4034056 & 13589 & 3,095 & 23 \\
\hline 2005-2007 & $(-0.065)$ & 1278766 & 4000513 & 12788 & $(2590)$ & $(20)$ \\
\hline 2008-2011 & $(-0.052)$ & 1438448 & 4067379 & 14384 & (2 096) & (15) \\
\hline \multicolumn{7}{|c|}{ Only US Citizens' Migration } \\
\hline $2005-2011$ & -0.076 & 1358869 & 4034056 & 13589 & 3,054 & 22 \\
\hline 2005-2007 & $(-0.058)$ & 1278766 & 4000513 & 12788 & (2 340) & $(18)$ \\
\hline 2008-2011 & $(-0.073)$ & 1438448 & 4067379 & 14384 & (2 989) & (21) \\
\hline \multicolumn{7}{|c|}{ Smaller Regions } \\
\hline \multicolumn{7}{|c|}{ EU-27/EFTA NUTS-2 } \\
\hline $2005-2011$ & -0.087 & 434882 & 1232524 & 4349 & 1,073 & 25 \\
\hline 2005-2007 & $(-0.042)$ & 428645 & 1229990 & 4286 & $(514)$ & $(12)$ \\
\hline 2008-2011 & -0.130 & 441080 & 1235043 & 4411 & 1603 & 36 \\
\hline \multicolumn{7}{|c|}{ Only EU Citizens' Migration } \\
\hline $2005-2011$ & -0.029 & 434882 & 1232524 & 4349 & 362 & 8 \\
\hline 2005-2007 & $(0.031)$ & 428645 & 1229990 & 4286 & $(-384)$ & $(-9)$ \\
\hline 2008-2011 & -0.062 & 441080 & 1235043 & 4411 & 768 & 17 \\
\hline \multicolumn{7}{|c|}{ Eurozone NUTS-2 } \\
\hline \multicolumn{7}{|c|}{ All Migration } \\
\hline $2005-2011$ & -0.099 & 455182 & 1288881 & 4552 & 1282 & 28 \\
\hline $2005-2007$ & $(-0.060)$ & 445437 & 1279495 & 4454 & $(764)$ & (17) \\
\hline \multirow{2}{*}{\multicolumn{7}{|c|}{ Only Eurozone Citizens' }} \\
\hline & & & & & & \\
\hline \multicolumn{7}{|c|}{ Migration } \\
\hline $2005-2011$ & $(-0.016)$ & 455182 & 1288881 & 4552 & $(200)$ & $(4)$ \\
\hline 2005-2007 & $(0.078)$ & 445437 & 1279495 & 4454 & $(-1001)$ & $(-22)$ \\
\hline 2008-2011 & $(-0.055)$ & 464986 & 1298304 & 4650 & $(714)$ & (15) \\
\hline $2005-2011$ & -0.087 & 129874 & 385768 & 1299 & 335 & All Migration \\
\hline $2005-2007$ & -0.135 & 121917 & 381686 & 1219 & 516 & 42 \\
\hline 2008-2011 & $(-0.030)$ & 137811 & 389840 & 1378 & $(116)$ & (8) \\
\hline Only US Cit & & & & & & \\
\hline $2005-2011$ & -0.087 & 129874 & 385768 & 1299 & 335 & 26 \\
\hline 2005-2007 & -0.145 & 121917 & 381686 & 1219 & 554 & 45 \\
\hline 2008-2011 & $(-0.023)$ & 137811 & 389840 & 1378 & (89) & (6) \\
\hline
\end{tabular}

Note: Values in brackets are not within significance level of $\mathrm{p}<0.1$.

Source: European Labour Force Survey, American Community Survey. 


\section{ANNEX 3: MAIN ORIGIN COUNTRIES}

Figure A1: Main origin countries of emigration to (other) EU-27/EFTA ${ }^{(1)}$ countries in 2011, by nationality

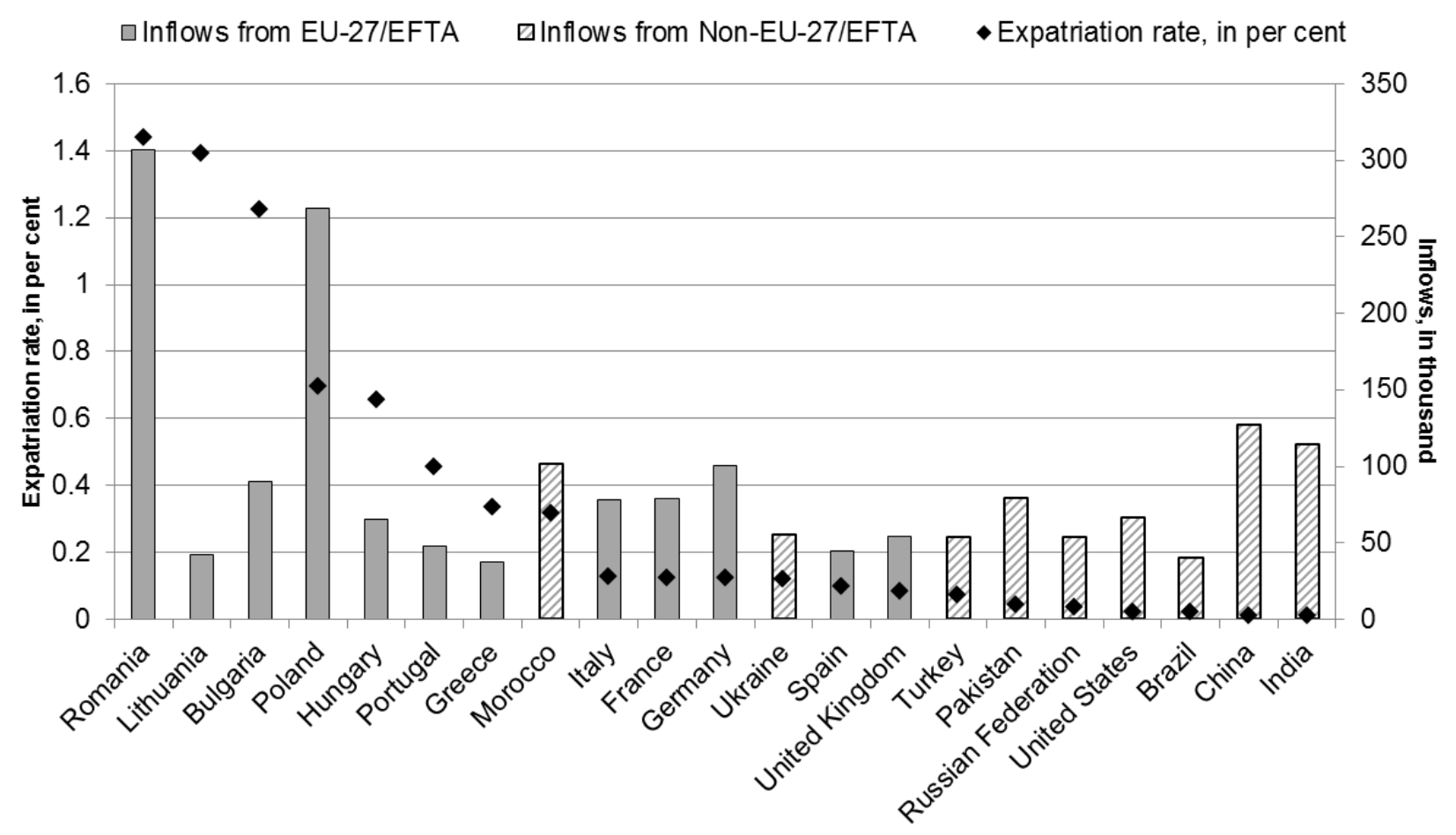

Source: OECD Secretariat calculations on the basis of the OECD International Migration Database, OECD Population Database and WDI World Bank.

Note: (1) Countries include all European OECD countries plus Lithuania and Latvia. 